\title{
Patellar resurfacing versus nonresurfacing in total knee arthroplasty: an updated meta-analysis of randomized controlled trials
}

\author{
Kai Chen ${ }^{1+}$, Xiaoyu Dai ${ }^{2 \dagger}$, Lidong $\mathrm{Li}^{1}$, Zhigang Chen ${ }^{1}$, Haidong Cui ${ }^{1}$ and Shujun Lv ${ }^{1 *}$
}

\begin{abstract}
Background: Whether resurface the patella or not in total knee arthroplasty (TKA) was controversial. In 2013, we conducted a meta-analysis of randomized controlled trials (RTCS). After that, plenty of studies have been carried out, but there still existed a great deal of controversy. In order to update our previous study, we conducted this update meta-analysis to evaluate the efficacy of patellar resurfacing in TKA.

Methods: Databases were searched for RCTs comparing the outcomes of patellar resurfacing and nonresurfacing in TKA. Outcomes of knee relevant indicators were analysed. To see the short- and long-term effects, we calculated the data in total and divided the patients who were followed up for $\leq 3$ years and $\geq 5$ years into two subgroups as well.

Results: Thirty-two trials assessing 6887 knees were eligible. There was a significant difference in terms of reoperation (in total and $\geq 5$ years), Knee Society Score (KSS), function score (in total and $\geq 5$ years) and noise. While no significant difference was found in the following items: reoperation ( $\leq 3$ years), anterior knee pain (AKP), function score ( $\leq 3$ years), range of motion (ROM), Oxford score, the Knee Injury and Osteoarthritis Outcome Score (KOOS), visual analogue score (VAS), Feller score, patellar tilt and the patients' satisfaction.

Conclusions: We found that patellar resurfacing could reduce the occurrence of reoperation and noise after surgery, as well as increase the KSS and function score, while it might not influence the outcomes such as AKP, ROM, Oxford score, KOOS, VAS, Feller score, patellar tilt and the patients' satisfaction. The results are different from our previous finding in the meta-analysis. In conclusion, we prefer patellar resurfacing in TKA.
\end{abstract}

Keywords: Patellar resurfacing, Total knee arthroplasty, Updated meta-analysis, Randomized controlled trial

\footnotetext{
* Correspondence: 1928659029@qq.com

${ }^{\dagger}$ Kai Chen and Xiaoyu Dai contributed equally to the work as co-first authors. 'Department of Orthopedic Surgery, Hai'an People's Hospital, Zhongba Road 17, Hai'an, Nantong 226600, Jiangsu, People's Republic of China

Full list of author information is available at the end of the article
}

(c) The Author(s). 2021 Open Access This article is licensed under a Creative Commons Attribution 4.0 International License, which permits use, sharing, adaptation, distribution and reproduction in any medium or format, as long as you give appropriate credit to the original author(s) and the source, provide a link to the Creative Commons licence, and indicate if changes were made. The images or other third party material in this article are included in the article's Creative Commons licence, unless indicated otherwise in a credit line to the material. If material is not included in the article's Creative Commons licence and your intended use is not permitted by statutory regulation or exceeds the permitted use, you will need to obtain permission directly from the copyright holder. To view a copy of this licence, visit http://creativecommons.org/licenses/by/4.0/ The Creative Commons Public Domain Dedication waiver (http://creativecommons.org/publicdomain/zero/1.0/) applies to the data made available in this article, unless otherwise stated in a credit line to the data. 


\section{Introduction}

Total knee arthroplasty (TKA) is one of the most common treatments for patients suffered knee arthritis. Nevertheless, the management of patella during TKA operation still remains controversial [1]. In previous literature reports, there are 3 strategies adopted by different surgeons: patellar resurfacing, patellar nonresurfacing and selective resurfacing $[2,3]$. But no consensus on the best management has been reached [4]. The outcome indicators such as Knee Society Score (KSS), function score of KSS, range of motion (ROM), anterior knee pain (AKP) postoperative and the ratio of reoperation are different in various studies [1-5]. The different outcomes of previous studies provide the basis for different choices of patellar resurfacing or not. In 2013, the author conducted a meta-analysis of randomized controlled trials [5]. We found that patellar resurfacing could reduce the risk of reoperation. And in a long-term follow-up, patellar resurfacing might make a difference of KSS. While in other aspects, the benefit of patellar resurfacing was limited. The limitation of our previous meta-analysis is the amount of high-quality randomized controlled trials. Since 2013, more and more RCTs, retrospective studies, even meta-analysis and systematic reviews have been carried out. Still, no clear conclusion has been drawn. In order to see if the result of our previous study has changed and update the latest data, we conducted this update meta-analysis of available RCTs to evaluate the efficacy of patellar resurfacing in TKA. Especially, we evaluated the items as follows: reoperation, AKP, KSS, function score, ROM, Oxford score, the Knee injury and Osteoarthritis Outcome Score (KOOS), visual analogue score (VAS) of pain, Feller score, patella tilt, noise after operation and patients' satisfaction. Data in total, follow-up no more than 3 years and no less than 5 years were calculated separately.

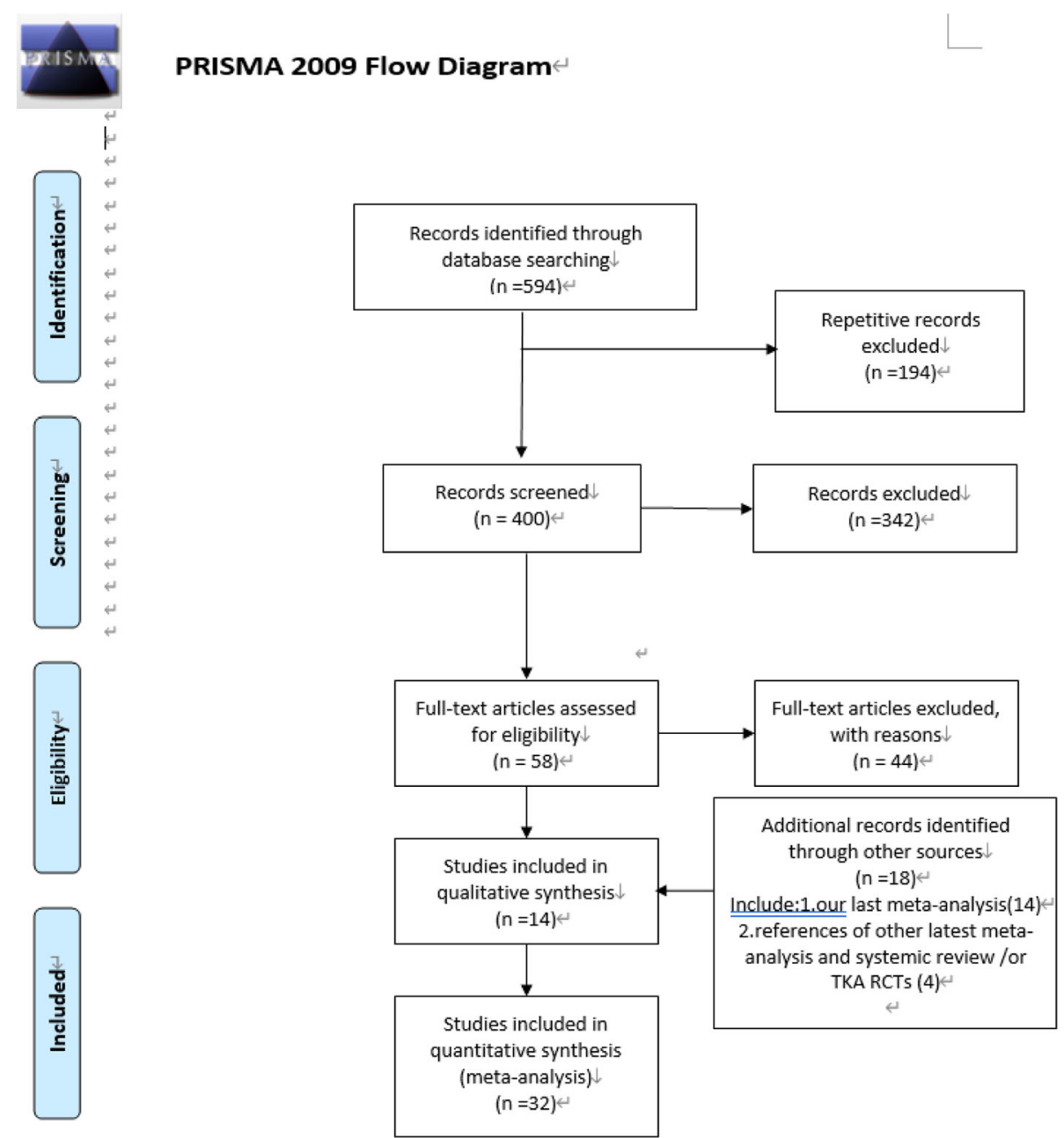

Fig. 1 Flow chart of the studies recruited in this meta-analysis 
Table 1 Characteristics of studies

\begin{tabular}{|c|c|c|c|c|c|c|c|c|c|c|}
\hline First author & Journal & $\begin{array}{l}\text { Year of } \\
\text { publication }\end{array}$ & $\begin{array}{l}\text { Num } \\
\text { of kn } \\
\text { (RS/ }\end{array}$ & $\begin{array}{l}\text { her } \\
\text { nees } \\
\text { NRS) }\end{array}$ & $\begin{array}{l}\text { Mean } \\
\text { age } \\
\text { (years) } \\
\text { (RS/NRS) }\end{array}$ & $\begin{array}{l}\text { Lost to } \\
\text { follow- } \\
\text { up } \\
\text { (knees) }\end{array}$ & $\begin{array}{l}\text { Mean } \\
\text { years } \\
\text { of } \\
\text { follow- } \\
\text { up }\end{array}$ & Outcomes & $\begin{array}{l}\text { Level of } \\
\text { evidence }\end{array}$ & $\begin{array}{l}\text { Type of knee } \\
\text { prosthesis }\end{array}$ \\
\hline Feller [6] & JBJS & 1996 & 19 & 19 & 70.8 & 2 & 2 & $\begin{array}{l}\text { HSS, patellar score, } \\
\text { pain, reoperation }\end{array}$ & I & PCA (HOWMEDICA) \\
\hline Kajino [7] & JBJS & 1997 & 26 & 26 & 56.1 & 0 & 6.6 & $\begin{array}{l}\text { HSS, pain, muscle } \\
\text { strength, patellar tilt }\end{array}$ & । & $\begin{array}{l}\text { Yoshino-Shoji } \\
\text { (Biomet) }\end{array}$ \\
\hline $\begin{array}{l}\text { Schroeder-Boersch } \\
\text { [8] }\end{array}$ & $\begin{array}{l}\text { Arch Orthop } \\
\text { Trauma Surg }\end{array}$ & 1998 & 20 & 20 & $73 / 72.2$ & 0 & 2 & $\begin{array}{l}\mathrm{KSS}, \mathrm{AKP}, \\
\text { radiographs, } \\
\text { reoperation }\end{array}$ & I & $\begin{array}{l}\text { Duracon } \\
\text { (HOWMEDICA) }\end{array}$ \\
\hline Newman [9] & Knee & 2000 & 42 & 42 & $72 / 71.2$ & 0 & 5 & AKP, reoperation & । & $\begin{array}{l}\text { Kinematic } \\
\text { (HOWMEDICA) }\end{array}$ \\
\hline Barrack [10] & JBJS & 2001 & 47 & 46 & 66.2 & 11 & $5-7$ & $\begin{array}{l}\text { KSS, AKP, ROM, } \\
\text { satisfaction, } \\
\text { reoperation }\end{array}$ & । & $\begin{array}{l}\text { Miller-Galante II } \\
\text { (ZIMMER) }\end{array}$ \\
\hline Wood [11] & JBJS & 2002 & 92 & 128 & $73.7 / 73.7$ & 22 & 4 & $\begin{array}{l}\text { KSS, AKP, reoperation, } \\
\text { satisfaction, patellar } \\
\text { tilt }\end{array}$ & I & $\begin{array}{l}\text { Miller-Galante II } \\
\text { (ZIMMER) }\end{array}$ \\
\hline Mayman [12] & $\mathrm{JOA}$ & 2003 & 50 & 50 & $72 / 68$ & 29 & 10 & $\begin{array}{l}\text { KSS, AKP, reoperation, } \\
\text { satisfaction }\end{array}$ & । & AMK (Depuy) \\
\hline Waters [13] & JBJS & 2003 & 243 & 231 & 69.1 & 0 & 5.3 & $\begin{array}{l}\text { KSS, AKP, satisfaction, } \\
\text { ROM, radiographs }\end{array}$ & । & $\begin{array}{l}\text { Press-fit condylar } \\
\text { prosthesis (Johnson } \\
\& \text { Johnson) }\end{array}$ \\
\hline Burnett [4] & CORR & 2004 & 42 & 48 & $71 / 69$ & 0 & 10 & $\begin{array}{l}\text { KSS, AKP, ROM, } \\
\text { satisfaction }\end{array}$ & । & AMK (Depuy) \\
\hline Gildone [14] & $\begin{array}{l}\text { Acta Orthop } \\
\text { Belg }\end{array}$ & 2005 & 28 & 28 & 73.6/74.6 & 0 & 2 & $\begin{array}{l}\text { KSS, daily activities, } \\
\text { ROM, satisfaction, } \\
\text { AKP }\end{array}$ & । & NexGen (ZIMMER) \\
\hline Campbell [15] & JBJS & 2006 & 46 & 54 & $71 / 73$ & 42 & 10 & $\begin{array}{l}\text { WOMAC, AKP, } \\
\text { radiographs, KSS }\end{array}$ & । & $\begin{array}{l}\text { Miller-Galante II } \\
\text { (ZIMMER) }\end{array}$ \\
\hline Myles [16] & $\begin{array}{l}\text { Clinical } \\
\text { Biomechanics }\end{array}$ & 2006 & 25 & 25 & 70 & 8 & 2 & $\begin{array}{l}\text { KSS, WOMAC, VAS, } \\
\text { reoperation }\end{array}$ & I & $\begin{array}{l}\text { LCS rotating } \\
\text { platform knee } \\
\text { replacement } \\
\text { (DePuy) }\end{array}$ \\
\hline Burnett [17] & CORR & 2007 & 28 & 28 & 78 & 8 & 10 & $\begin{array}{l}\text { AKP, } \mathrm{ROM} \text {, } \\
\text { reoperation }\end{array}$ & । & $\begin{array}{l}\text { Miller-Galante II } \\
\text { (ZIMMER) }\end{array}$ \\
\hline Smith [18] & JBJS & 2008 & 73 & 86 & 71.9/71.2 & 7 & 4 & $\begin{array}{l}\text { KSS, AKP, satisfaction, } \\
\text { radiographs, } \\
\text { reoperation }\end{array}$ & I & $\begin{array}{l}\text { Profix total knee } \\
\text { system (Smith \& } \\
\text { Nephew) }\end{array}$ \\
\hline Burnett [19] & JBJS & 2009 & 58 & 60 & $65.3 / 67.1$ & 40 & 10 & $\begin{array}{l}\text { ROM, KSS, AKP, } \\
\text { satisfaction }\end{array}$ & $\|$ & $\begin{array}{l}\text { Miller-Galante II } \\
\text { (ZIMMER) }\end{array}$ \\
\hline Breeman [20] & JBJS & 2011 & 861 & 854 & $70 / 70$ & 405 & 5 & $\begin{array}{l}\text { Oxford score, SF-12, } \\
\text { EuroQol-5d, cost- } \\
\text { effective, reoperation }\end{array}$ & I & No mention \\
\hline Beaupre [21] & $\begin{array}{l}\text { BMC Research } \\
\text { Notes }\end{array}$ & 2012 & 21 & 17 & $64.9 / 62$ & 15 & 10 & $\begin{array}{l}\text { WOMAC, reoperation, } \\
\text { ROM, Rand } 36 \text { score }\end{array}$ & I & $\begin{array}{l}\text { Profic total knee } \\
\text { system }\end{array}$ \\
\hline Liu [22] & Knee & 2012 & 68 & 64 & $67.5 / 68$ & 12 & 7 & $\begin{array}{l}\text { KSS, AKP, ROM, } \\
\text { radiographs, } \\
\text { reoperation }\end{array}$ & । & $\begin{array}{l}\text { Press-fit condylar } \\
\text { prosthesis (DePuy) }\end{array}$ \\
\hline $\begin{array}{l}\text { Ferguson (FB) } \\
\text { Feguson (MB) [23] }\end{array}$ & Knee & 2014 & $\begin{array}{l}88 \\
89\end{array}$ & $\begin{array}{l}88 \\
87\end{array}$ & $\begin{array}{l}69.8 \\
70.2\end{array}$ & $\begin{array}{l}13 \\
13\end{array}$ & 2 & $\begin{array}{l}\text { Oxford score, ROM, } \\
\text { SF-12 score, } \\
\text { reoperation }\end{array}$ & । & $\begin{array}{l}\text { Press-fit condylar } \\
\text { prosthesis (DePuy) }\end{array}$ \\
\hline Murray [24] & $\begin{array}{l}\text { Health } \\
\text { Technology } \\
\text { Assessment }\end{array}$ & 2014 & 816 & 798 & $70 / 70$ & 824 & 10 & $\begin{array}{l}\text { Oxford score, } \\
\text { EuroQol-5d, SF-12 } \\
\text { score, reoperation }\end{array}$ & । & No mention \\
\hline Sreehari [25] & $\mathrm{AO}$ & 2014 & 75 & 60 & $68.1 / 65.8$ & 0 & 5 & KSS, AKP, ROM, & । & No mention \\
\hline
\end{tabular}


Table 1 Characteristics of studies (Continued)

\begin{tabular}{|c|c|c|c|c|c|c|c|c|c|c|}
\hline First author & Journal & $\begin{array}{l}\text { Year of } \\
\text { publication }\end{array}$ & $\begin{array}{l}\text { Num } \\
\text { of kn } \\
\text { (RS/ } /\end{array}$ & $\begin{array}{l}\text { iber } \\
\text { nees } \\
\text { NRS) }\end{array}$ & $\begin{array}{l}\text { Mean } \\
\text { age } \\
\text { (years) } \\
\text { (RS/NRS) }\end{array}$ & $\begin{array}{l}\text { Lost to } \\
\text { follow- } \\
\text { up } \\
\text { (knees) }\end{array}$ & $\begin{array}{l}\text { Mean } \\
\text { years } \\
\text { of } \\
\text { follow- } \\
\text { up }\end{array}$ & Outcomes & $\begin{array}{l}\text { Level of } \\
\text { evidence }\end{array}$ & $\begin{array}{l}\text { Type of knee } \\
\text { prosthesis }\end{array}$ \\
\hline & Orthopaedics & & & & & & & reoperation & & \\
\hline Roberts [26] & $\mathrm{JOA}$ & 2015 & 178 & 172 & $70.2 / 71.3$ & 236 & 10.4 & $\begin{array}{l}\text { KSS, ROM, } \\
\text { reoperation, AKP, } \\
\text { satisfaction }\end{array}$ & । & DePuy Sigma \\
\hline Ali [27] & $\begin{array}{l}\text { Acta } \\
\text { Orthopaedica }\end{array}$ & 2016 & 33 & 36 & $68 / 69$ & 5 & 6 & $\begin{array}{l}\text { VAS, KOSS, } \\
\text { satisfaction, } \\
\text { reoperation }\end{array}$ & । & Triathlon CR \\
\hline Aunan [28] & $\begin{array}{l}\text { Acta } \\
\text { Orthopaedica }\end{array}$ & 2016 & 63 & 66 & $70 / 69$ & 1 & 3 & $\begin{array}{l}\text { KOSS, KSS, Oxford } \\
\text { score, VAS, } \\
\text { satisfaction, } \\
\text { reoperation }\end{array}$ & । & NexGen (ZIMMER) \\
\hline Vukadin [29] & $\begin{array}{l}\text { Acta } \\
\text { Chirurgiae } \\
\text { Orthopaedicae }\end{array}$ & 2017 & 30 & 29 & $68.1 / 66$ & 1 & 2 & $\begin{array}{l}\text { KSS, Oxford score, } \\
\text { reoperation }\end{array}$ & । & Unknown \\
\hline Dong [30] & $\mathrm{JOA}$ & 2018 & 48 & 48 & 67.7 & 6 & 3 & $\begin{array}{l}\text { KSS, Feller score, AKP, } \\
\text { reoperation }\end{array}$ & । & $\begin{array}{l}\text { Posterior cruciate } \\
\text { stabilizing total knee } \\
\text { prostheses (Smith \& } \\
\text { Nephew) }\end{array}$ \\
\hline Kaseb [31] & ABJS & 2018 & 24 & 26 & 64.8 & 0 & 0.5 & $\begin{array}{l}\text { KSS, AKP, WOMAC, } \\
\text { SF- } 36 \text { score, ROM, } \\
\text { VAS, reoperation }\end{array}$ & । & Profix (ZIMMER) \\
\hline $\mathrm{Ha}[32]$ & $\begin{array}{l}\text { International } \\
\text { Orthopaedics }\end{array}$ & 2019 & 60 & 60 & 65.2 & 12 & 5 & $\begin{array}{l}\mathrm{KSS}, \mathrm{AKP} \text {, satisfaction, } \\
\text { reoperation }\end{array}$ & । & $\begin{array}{l}\text { Scorpoo NRG knee } \\
\text { prosthesis (Stryker) }\end{array}$ \\
\hline Kaseb [33] & ABJS & 2019 & 29 & 44 & $\begin{array}{l}68.1 / \\
65.75\end{array}$ & 0 & $\begin{array}{l}8.68 \\
\text { months }\end{array}$ & KSS, KOSS & । & $\begin{array}{l}\text { NexGen fixed } \\
\text { bearing knee } \\
\text { prosthesis (ZIMMER) }\end{array}$ \\
\hline Koh [34] & KSSTA & 2019 & 49 & 49 & 70 & 0 & 5 & $\begin{array}{l}\text { AKP, forgotten score, } \\
\text { ROM, WOMAC, } \\
\text { reoperation, Feller } \\
\text { score, radiograph }\end{array}$ & । & $\begin{array}{l}\text { Posterior stabilized } \\
\text { knee system (Lospa) }\end{array}$ \\
\hline $\begin{array}{l}\text { Thiengwittayaporn } \\
\text { [35] }\end{array}$ & JOA & 2019 & 41 & 39 & $68.2 / 68.2$ & 4 & 1 & $\begin{array}{l}\text { KSS, AKP, Oxford } \\
\text { score, ROM, patellar } \\
\text { score, patellar tilt }\end{array}$ & । & $\begin{array}{l}\text { Legion PS (Smith \& } \\
\text { Nephew) }\end{array}$ \\
\hline Raaij [36] & J Knee Surg & 2020 & 21 & 21 & Unknown & 0 & 2 & $\begin{array}{l}\text { HSS, KSS, KOSS, } \\
\text { reoperation }\end{array}$ & I & Unknown \\
\hline
\end{tabular}

RS Resurfacing, NRS Nonresurfacing, AKP Anterior knee pain, KSS Knee Society Score, HSS Hospital for special surgery, ROM Range of motion, WOMAC Western Ontario McMaster Osteoarthritis Index, KOOS Knee Injury and Osteoarthritis Outcome Score

\section{Materials and methods}

\section{Identification and eligibility of relevant RCTs}

We carried out a literature search using MEDLINE, Ovid and Cochrane Library databases to identify all papers published from January 2013 to May 2020 that evaluated the outcome of patients undertaking TKA with patellar resurfacing or not. Utilizing the methodology of our previously published meta-analysis, the inclusion criteria for this study included [5] (1) English publications, (2) adults undergoing primary TKA, (3) all available RCTs comparing TKAs with and without patellar resurfacing and (4) data for the ratio of reoperation, AKP, knee scores (KSS, function score, Oxford score, KOOS, VAS, Feller score), ROM, patella tilt and noise after operation such as crepitus and patients' satisfaction. The exclusion criteria were non-English language articles, proceedings of meetings, unpublished data, nonrandomized controlled studies, studies of body specimens and researches of TKA but not about patellar resurfacing. To avoid double-counting, multiple publications of the same patient population were pooled as one study. In order to avoid the loss of included literatures, we did not use advanced search strategy this time. And our search words were "patellar resurfacing", "patellar replacement", "total knee arthroplasty" and "total knee replacement". The references of present meta-analysis, systematic reviews and review articles were also been searched from the databases for any missed studies. In the end, we added the 14 RCTs before 2013 in our previous study into this study. 


\section{Outcomes}

The researchers sorted the data successively for further analysis as follows: the number of reoperation, the number of patients suffered AKP postoperative, KSS, function score, ROM, Oxford score, KOOS, VAS, Feller score, patella tilt, noise after operation and patients' satisfaction. To see the short- and long-term effects, we calculated the data in total, follow-up no more than 3 years and no less than 5 years separately.

\section{Data extraction}

Two of the authors extracted the relevant data from each article independently. And a third researcher checked the data against the original information to avoid anthropic mistakes. The extracted data included publication and patients' characteristics, length of follow-up and numbers of lost to follow-up, knee prosthesis used in TKA and clinical outcomes (AKP, ROM, KSS, Function score and so on).

\section{Assessment of methodological quality}

Included studies were independently rated for methodological quality by two of the authors. Any controversy was cross-checked and resolved by a third author to reach a final consensus. The risks of bias in included studies were accessed using the Cochrane Risk of Bias Tool (Review Manager 5.4). The items assessed were (1) random sequence generation (selection bias), (2) allocation concealment (selection bias), (3) blinding of participants and personnel (performance bias), (4) blinding of outcome assessment (detection bias), (5) incomplete outcome data (attrition bias), (6) selective reporting (reporting bias) and (7) other biases.

\section{Statistical analysis}

The software Review Manager 5.4 (Cochrane Library) was used to analyse the included data. Fixed model or random-effects model were chosen based on the heterogeneity of the studies. A $P$ value of $<0.1$ and $I^{2}<25 \%$ were considered suggestive of statistical heterogeneity. The mean difference and 95\% confidence (95\%CI) were used for continuous data (such as ROM, scores, patellar tilt), while the risk ratios and 95\%CI were used for dichotomous outcomes such as reoperation and AKP.

\section{Results}

A flow chart of the recruited studies was shown in Fig. 1. Thirty-two trials [4, 6-36] assessing 6887 knees were selected for inclusion in this meta-analysis. Details on all the studies are shown in Table 1. The methodological quality is shown in Fig. 2 to see the bias risk of each study.

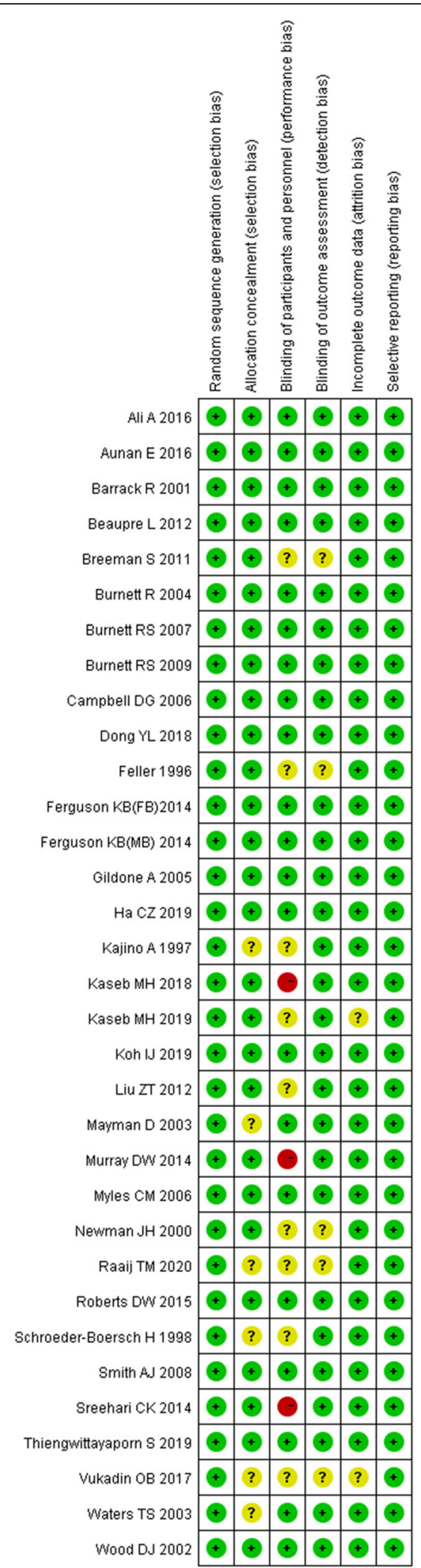

Fig. 2 Risk of bias 


\section{Reoperation}

A total of 5391 knees were included when comparing the ratio of reoperation for any reason postoperative which was described in 30 studies. The funnel plot showed low publication bias of the 30 researches (Fig. $3)$. The risk ratio $(\mathrm{RR})(\mathrm{RR}=0.63,95 \% \mathrm{CI} 0.54 \sim 0.73, P<$ 0.00001 , Fig. 4) implied that there was a significant difference between the two groups. And the test for homogeneity was not significant $(P=0.75)$. We could draw a conclusion that patellar resurfacing could reduce the reoperation rate postoperative. In addition, we analysed reoperation of 10 studies with a follow-up of no more than 3 years. The test for homogeneity showed no significant difference $(P=0.72)$. No significant difference was found between the reoperation data of the 2 groups $(\mathrm{RR}=0.57,95 \% \mathrm{CI} 0.26 \sim 1.25, P=0.16$, Fig. 5). Eighteen studies included data no less than 5 years. The test for homogeneity showed no significant difference $(P=0.44)$. A significant difference was found between the reoperation data of the 2 groups ( $\mathrm{RR}=0.62,95 \% \mathrm{CI} 0.53 \sim 0.72, P$ $<0.00001$, Fig. 6).

\section{Anterior knee pain}

Sixteen studies included 2163 knees reported on the incidence of AKP. The risk ratio for AKP was not significant in total $(\mathrm{RR}=0.75,95 \% \mathrm{CI} 0.49 \sim 1.14, P=$ 0.18 , Fig. 7), while the test for homogeneity showed significant difference $(P<0.00001)$. Four studies reported on data $\leq 3$ years $(\mathrm{RR}=0.73,95 \% \mathrm{CI} 0.32 \sim 1.69, P=0.46$, Fig. 8), and 11 studies reported on data $\geq 5$ years $(\mathrm{RR}=$ $0.79,95 \%$ CI $0.43 \sim 1.43, P=0.43$, Fig. 9). All the analyses showed that there was no remarkable difference in AKP between the resurfacing group and the nonresurfacing group.

\section{Knee Society Score}

Eighteen studies included 2265 knees reported on the necessary data of KSS. The mean difference (MD) for KSS was significant in total $(\mathrm{MD}=1.04,95 \% \mathrm{CI}$ $0.54 \sim 1.54, P<0.00001$, Fig. 10). And the test for homogeneity showed no significant difference $(P=0.24)$. Thirteen studies reported on data $\leq 3$ years $(\mathrm{MD}=0.77$, 95\%CI 0.08 1.47, $P=0.03$, Fig. 11), and 6 studies reported on data $\geq 5$ years $(\mathrm{MD}=1.31,95 \%$ CI $0.70 \sim 1.93$, $P<0.00001$, Fig. 12). All the analyses showed that there was a significant difference of KSS between the resurfacing group and the nonresurfacing group. It seemed that the patellar resurfacing group might get higher KSS scores after primary surgery.

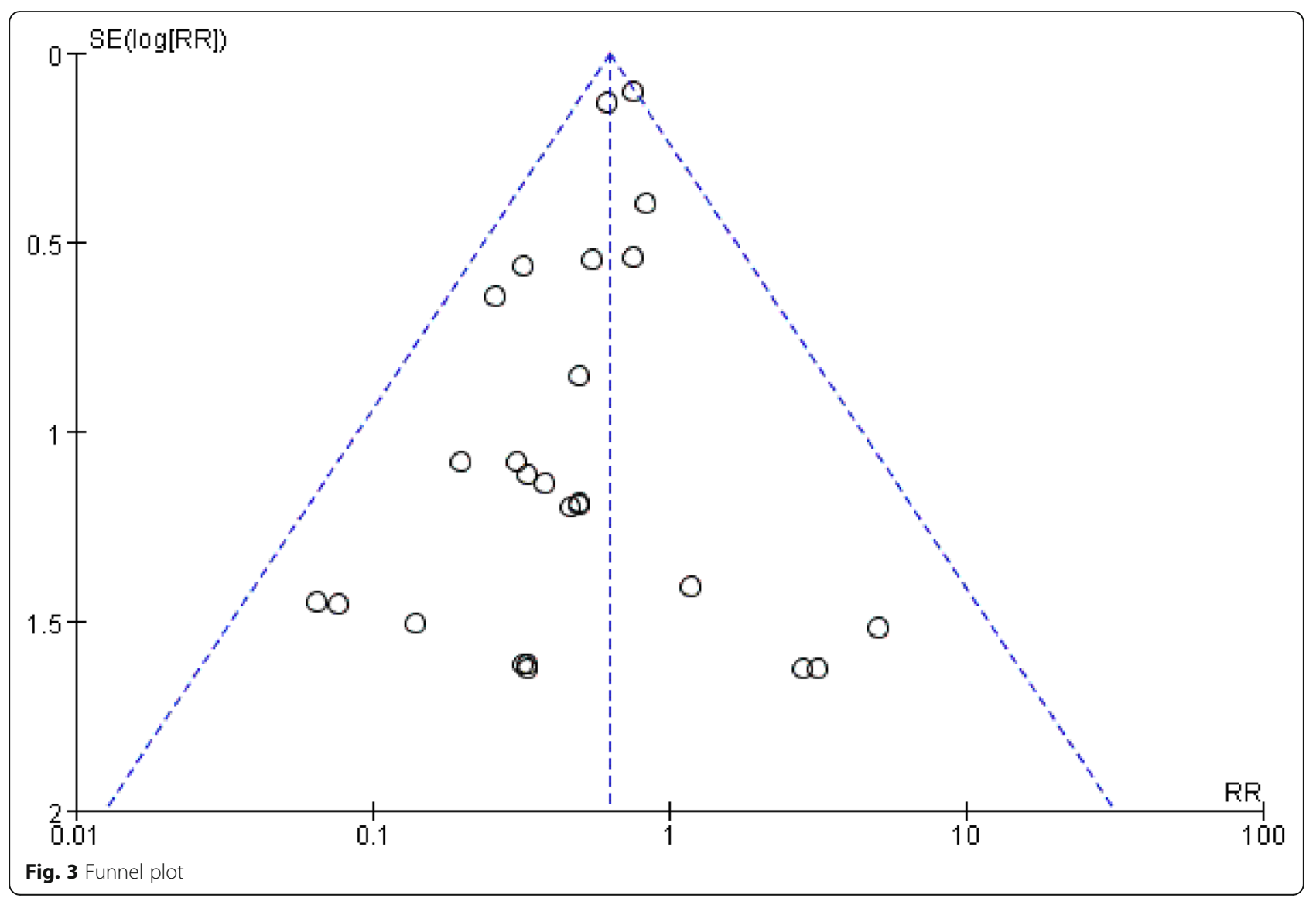




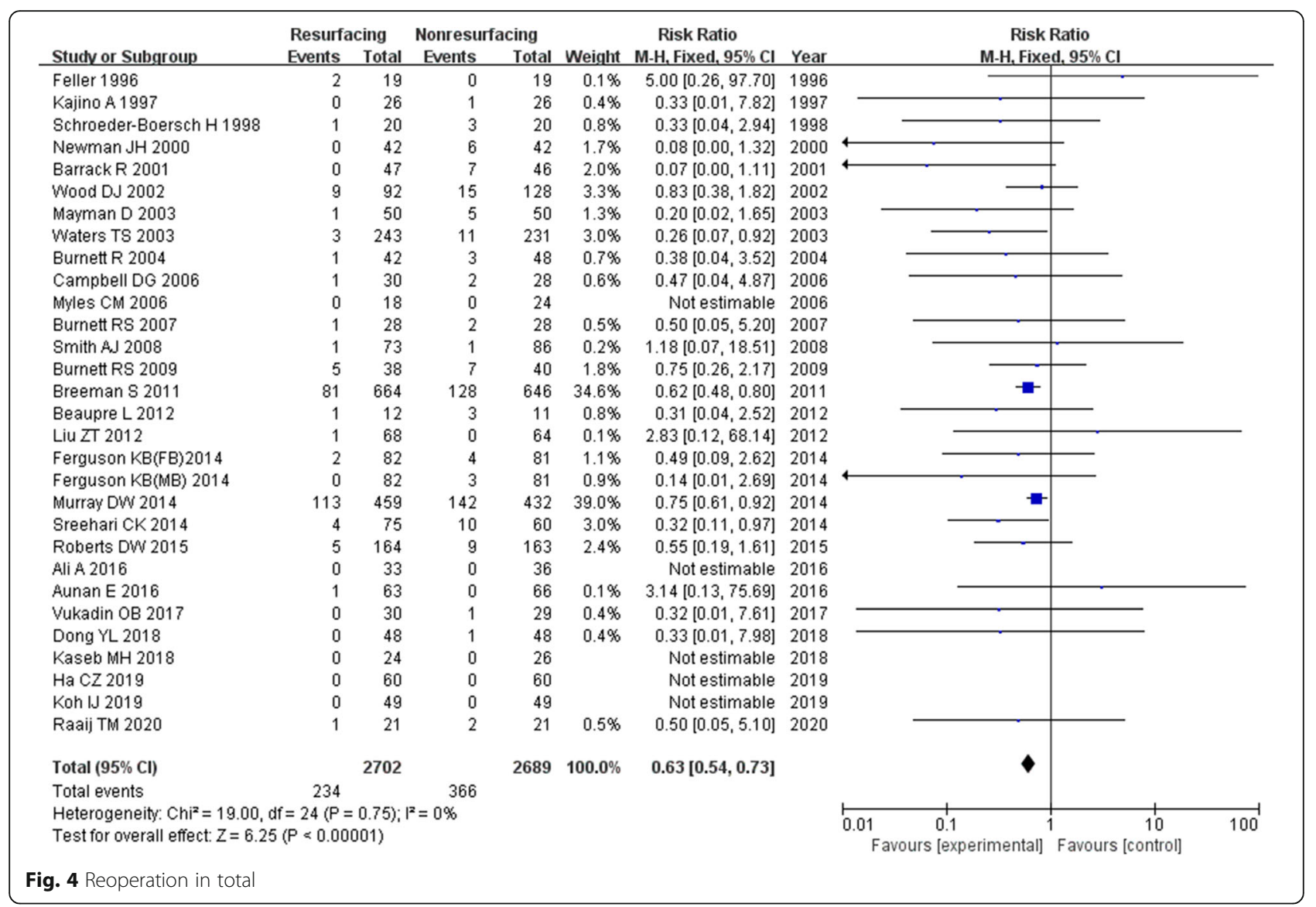

\section{Function score}

The function score was the function component of KSS. In our study, 16 studies of 1989 knees showed a function score. There was a significant difference between the two groups in total and for $\geq 5$ years, while the difference $\leq 3$ years was not significant (in total $\mathrm{MD}=1.91$, 95\%CI 1.06 2.77, $P<0.00001$, Fig. $13 ; \leq 3$ years $\mathrm{MD}=$ $1.41,95 \% \mathrm{CI}-0.22 \sim 3.05, P=0.09$, Fig. $14 ; \geq 5$ years $\mathrm{MD}$
$=2.26,95 \%$ CI 1.19 3.32, $P<0.00001$, Fig. 15). The $P$ value of heterogeneity was 0.22 showing low heterogeneity.

\section{Range of motion}

Six studies included 829 knees reported on necessary data of ROM. It seemed that there was no significant difference between the two groups after operation (in

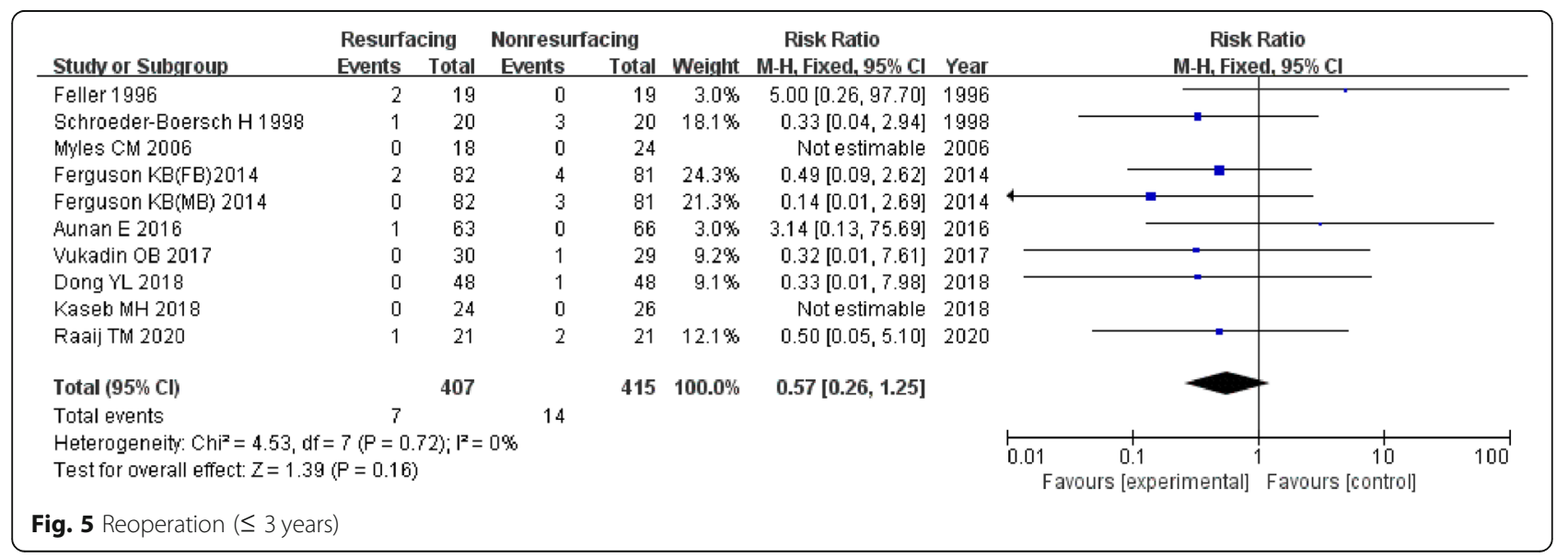




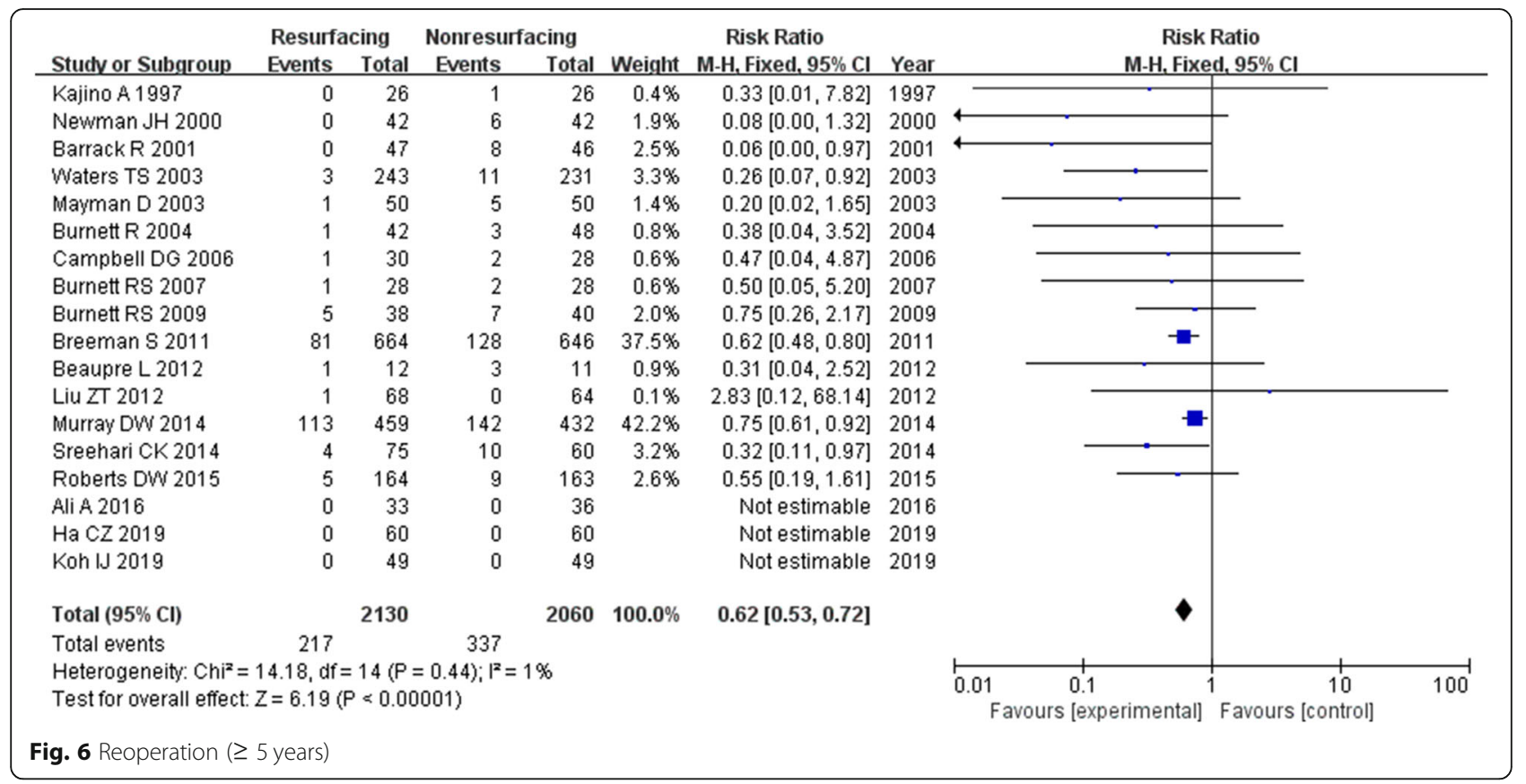

total $\mathrm{MD}=-0.60,95 \% \mathrm{CI}-2.27 \sim 1.08, P=0.49$, Fig. 16 ; $\leq 3$ years $\mathrm{MD}=-0.33,95 \% \mathrm{CI}-2.19 \sim 1.52, P=$ 0.72 ; $\geq 5$ years $\mathrm{MD}=-0.34,95 \% \mathrm{CI}-3.21 \sim 2.52, P<$ 0.81 ). The $P$ value of heterogeneity was 0.45 showing low heterogeneity.

\section{Oxford score}

Six studies included 2569 knees reported on necessary data of Oxford score. It seemed that there was no significant difference between the resurfacing group and the nonresurfacing group (in total $\mathrm{MD}=-0.65$, 95\%CI $-0.34 \sim 1.63, P=0.20$, Fig. 17 ; $\leq 3$ years $\mathrm{MD}=$ $0.51,95 \%$ CI $-0.40 \sim 1.41, P=0.27$; $\geq 5$ years only 2 studies).

\section{The Knee Injury and Osteoarthritis Outcome Score}

Three studies included 277 knees reported on necessary data of KOOS score. There was no significant difference between the two groups (in total MD $=2.16$, 95\%CI 1.91 6.23, $P=0.30$, Fig. 18).

\begin{tabular}{|c|c|c|c|c|c|c|c|c|c|c|}
\hline \multirow[b]{2}{*}{ Study or Subgroup } & \multicolumn{2}{|c|}{ Resurfacing } & \multicolumn{2}{|c|}{ Nonresurfacing } & \multicolumn{3}{|c|}{ Risk Ratio } & \multirow{2}{*}{\multicolumn{3}{|c|}{$\begin{array}{c}\text { Risk Ratio } \\
\text { M-H, Random, } 95 \% \mathrm{Cl}\end{array}$}} \\
\hline & Events & Total & Events & Total & Weight & M-H, Random, $95 \% \mathrm{Cl}$ & Year & & & \\
\hline Newman JH 2000 & 0 & 42 & 10 & 42 & $1.9 \%$ & $0.05[0.00,0.79]$ & 2000 & & & \\
\hline BarrackR 2001 & 9 & 47 & 8 & 46 & $7.4 \%$ & $1.10[0.47,2.61]$ & 2001 & & & \\
\hline Wood D.J 2002 & 15 & 92 & 39 & 128 & $9.1 \%$ & $0.54[0.31,0.91]$ & 2002 & & & \\
\hline Waters TS 2003 & 13 & 243 & 58 & 231 & $8.9 \%$ & $0.21[0.12,0.38]$ & 2003 & & & \\
\hline Burnett R 2004 & 7 & 19 & 5 & 20 & $6.9 \%$ & $1.47[0.56,3.85]$ & 2004 & & & \\
\hline Gildone A 2005 & 0 & 28 & 6 & 28 & $1.8 \%$ & $0.08[0.00,1.30]$ & 2005 & & & \\
\hline Campbell DG 2006 & 14 & 30 & 12 & 28 & $8.9 \%$ & $1.09[0.61,1.93]$ & 2006 & & & \\
\hline Burnett RS 2007 & 4 & 28 & 5 & 28 & $5.7 \%$ & $0.80[0.24,2.67]$ & 2007 & & & \\
\hline Smith AJ 2008 & 22 & 73 & 18 & 86 & $9.1 \%$ & $1.44[0.94,2.47]$ & 2008 & & & \\
\hline Burnett RS 2009 & 8 & 38 & 6 & 40 & $6.9 \%$ & $1.40[0.54,3.67]$ & 2009 & & & \\
\hline Liu ZT 2012 & 10 & 68 & 8 & 64 & $7.4 \%$ & $1.18[0.50,2.79]$ & 2012 & & & \\
\hline Roberts DW 2015 & 10 & 158 & 9 & 162 & $7.3 \%$ & $1.14[0.48,2.73]$ & 2015 & & & \\
\hline Dong YL 2018 & 8 & 48 & 9 & 48 & $7.4 \%$ & $0.89[0.37,2.11]$ & 2018 & & & \\
\hline $\mathrm{HaCZ} 2019$ & 3 & 60 & 14 & 60 & $5.7 \%$ & $0.21[0.06,0.71]$ & 2019 & & & \\
\hline Koh IJ 2019 & 4 & 49 & 2 & 49 & $4.1 \%$ & $2.00[0.38,10.42]$ & 2019 & & & \\
\hline Thiengwittayaporn 82019 & 0 & 41 & 2 & 39 & $1.7 \%$ & $0.19[0.01,3.85]$ & 2019 & & & \\
\hline Total $(95 \% \mathrm{Cl})$ & & 1064 & & 1099 & $100.0 \%$ & $0.75[0.49,1.14]$ & & & & \\
\hline \multirow{2}{*}{\multicolumn{8}{|c|}{$\begin{array}{l}\text { Heterogeneity: } \text { Tau }^{2}=0.43 ; \mathrm{Ch}^{2}=48.94, \mathrm{df}=15(\mathrm{P}=0.0001) ;\left.\right|^{2}=69 \% \\
\text { Test for overall effect: } Z=1.34(\mathrm{P}=0.18)\end{array}$}} & & & \\
\hline & & & & & & & & $\begin{array}{ccc}0.01 & 0.1 \\
& \text { Favours [experimental] }\end{array}$ & 10 & 100 \\
\hline
\end{tabular}




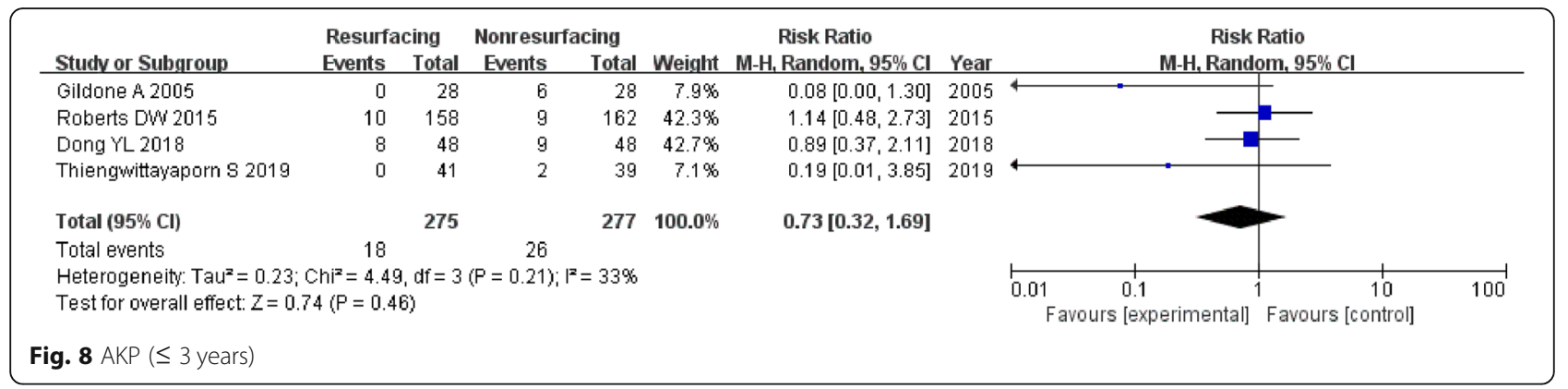

\section{VAS}

Three studies included 217 knees reported on necessary data of VAS score. There was no significant difference between the two groups (in total $\mathrm{MD}=-0.10,95 \% \mathrm{CI}-$ $0.42 \sim 0.22, P=0.55)$.

\section{Feller score}

Three studies included 274 knees reported on necessary data of Feller score. There was no significant difference between the two groups (in total $\mathrm{MD}=0.31,95 \% \mathrm{CI}-$ $0.8 \sim 1.43, P=0.59$ ).

\section{Patellar tilt}

Five studies included 444 knees reported on necessary data of patellar tilt angle. There was no significant difference between the two groups (in total $\mathrm{MD}=-0.03$, $95 \% \mathrm{CI}-0.36 \sim 0.30, P=0.86$ ).

\section{Noise after operation}

Five studies included 503 knees reported on necessary data of the appearance of noise such as clunk, crepitus and so on. There was a significant difference between the two groups (in total $\mathrm{RR}=0.47,95 \% \mathrm{CI} 0.32 \sim 0.68, P$
$<0.00001)$. It seemed that patellar resurfacing might reduce the occurrence of noise postoperative.

\section{Patients satisfaction}

We got 10 studies of 1382 knees showing the number of patients satisfied with the operation (Fig. 19). It seemed that there was no significant difference between the two groups (in total $\mathrm{RR}=1.24,95 \% \mathrm{CI} 0.73 \sim 2.10, P=0.44$ ), while the $P$ value of heterogeneity was 0.007 , which showed high heterogeneity.

\section{Discussion}

In this meta-analysis, 32 randomized controlled trials assessing 6887 knees were adopted. We analysed the data by different statistical indicators and follow-up periods ( 3 subgroups: in total, $\leq 3$ years and $\geq 5$ years ). In summary, we found that there was a significant difference between the two groups in terms of reoperation (in total and $\geq 5$ years), KSS (all 3 subgroups), function score (in total and $\geq 5$ years) and noise postoperation, while no significant difference was found between the resurfacing and the nonresurfacing group in the following items: reoperation ( $\leq 3$ years), AKP (all 3 subgroups), function score ( $\leq 3$ years), ROM,

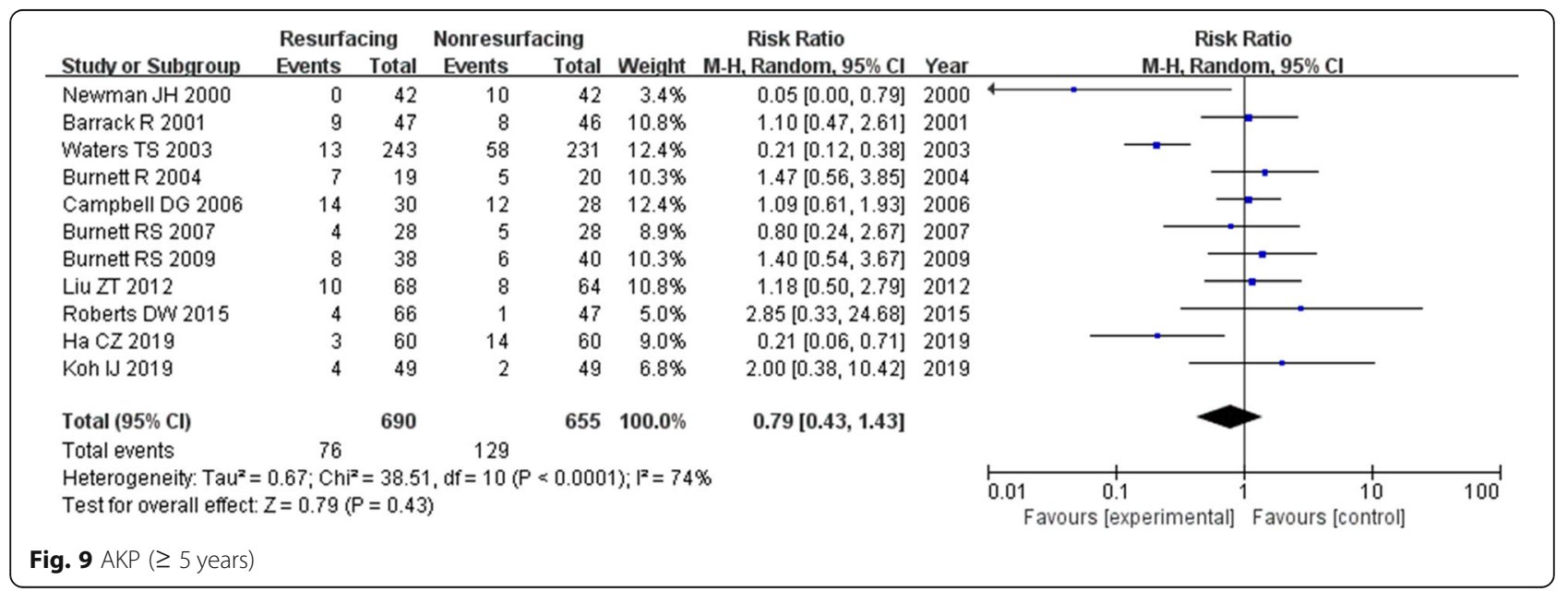




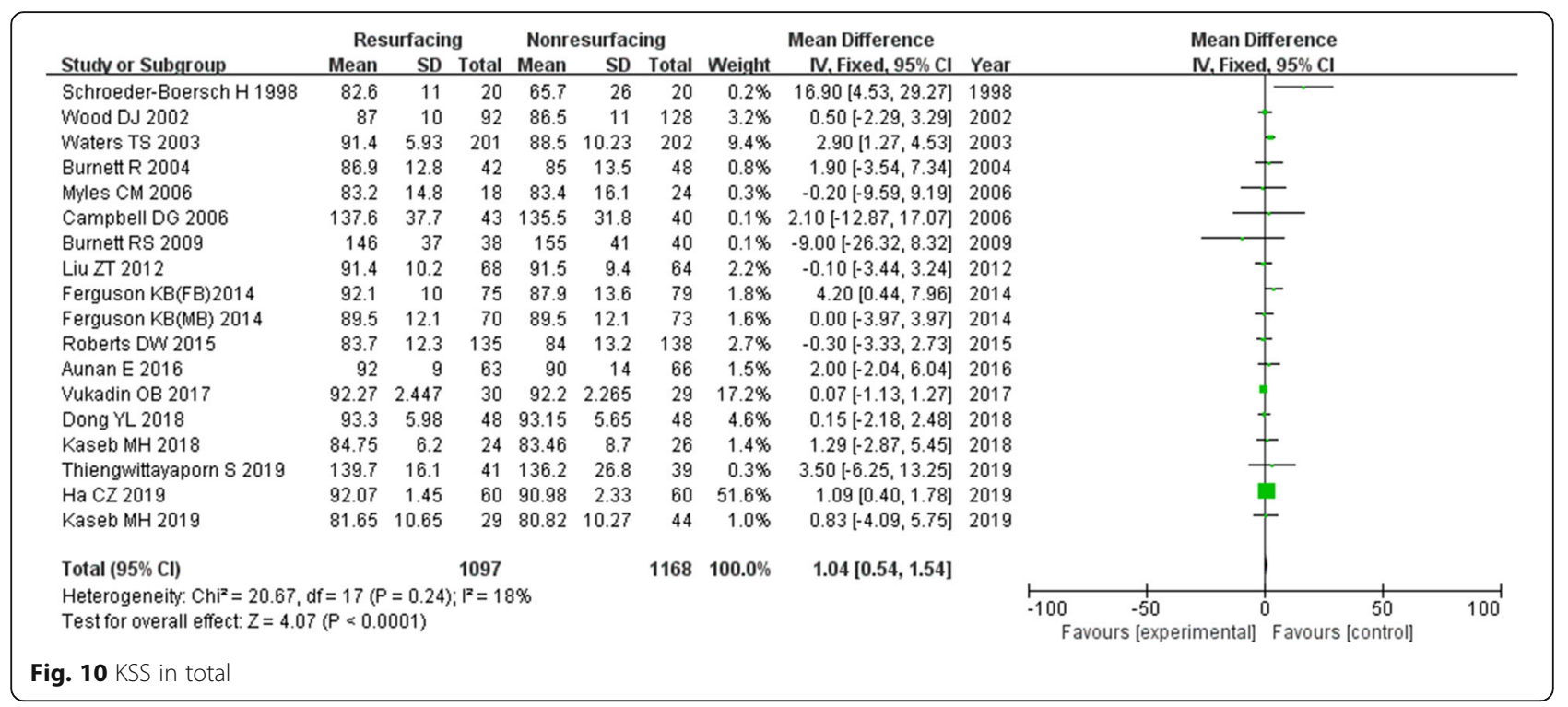

Oxford score, KOOS, VAS, Feller score, patellar tilt and the patients' satisfaction. We could conclude that patellar resurfacing might reduce the occurrence of reoperation and noise after surgery, as well as increase the KSS and function score. Especially, the noise syndrome, such as clunk, crepitus and so on, was seen in some of the latest studies. Ha et al. and we got the same conclusion that patellar resurfacing might reduce the ratio of noise after primary TKA surgery [32], while the relationship between noise and other scores was not clear. The results of reoperation and function score for $\leq 3$ years were not significantly different in our study. This indicated that the followup periods might affect the outcome indicators. Nevertheless, our study showed that patellar resurfacing might not influence the results such as AKP,
ROM, Oxford score, KOOS, VAS, Feller score, patellar tilt and the patients' satisfaction compared with nonresurfacing. Especially for the AKP result, the findings of our study are close to that in Teel et al.'s meta-analysis and different from Migliorini et al.'s study $[37,38]$.

During the implementation process of our study, we searched a great many literatures comparing patellar resurfacing versus nonresurfacing in TKA. Though the non-RCTs were excluded from this study, we still read the literature as well as previous meta-analysis and systemic reviews thoroughly. Twenty-two nonRCTs [39-60] and 15 meta-analysis or systemic reviews $[2,5,37,38,61-71]$ were singled out ever since 2013. In the non-RCT studies, nine stated that there was no difference between patellar resurfacing and

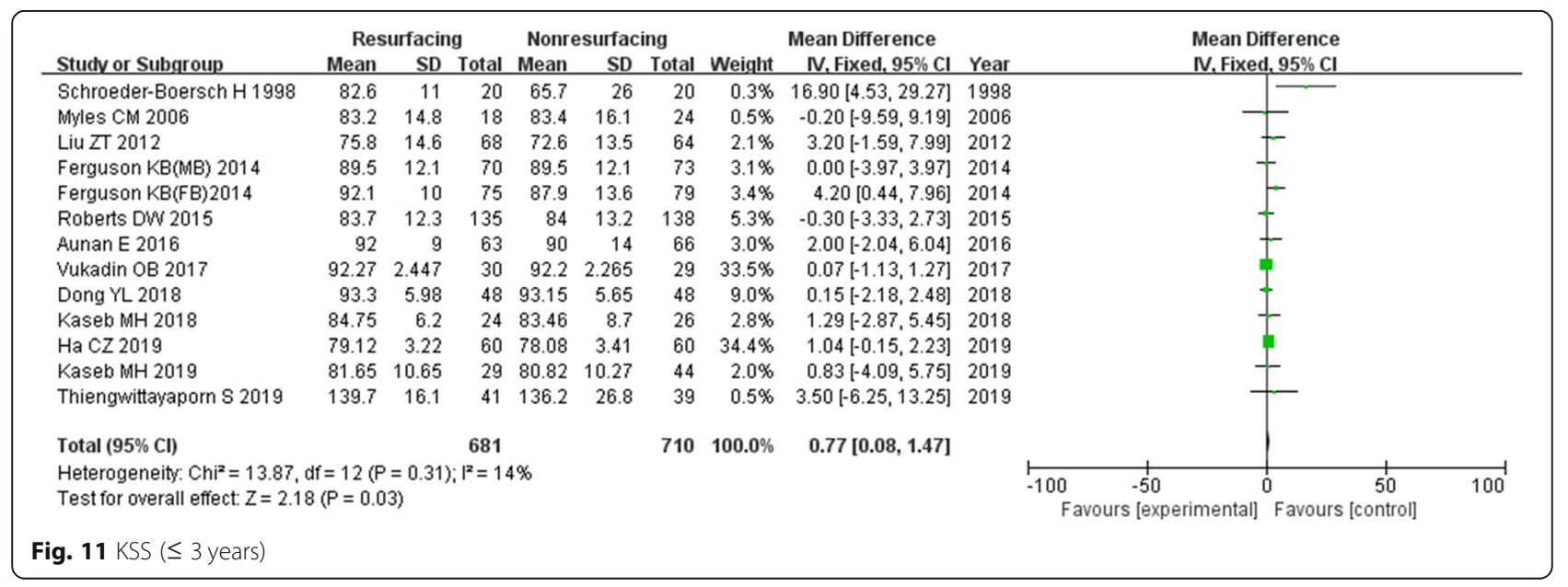




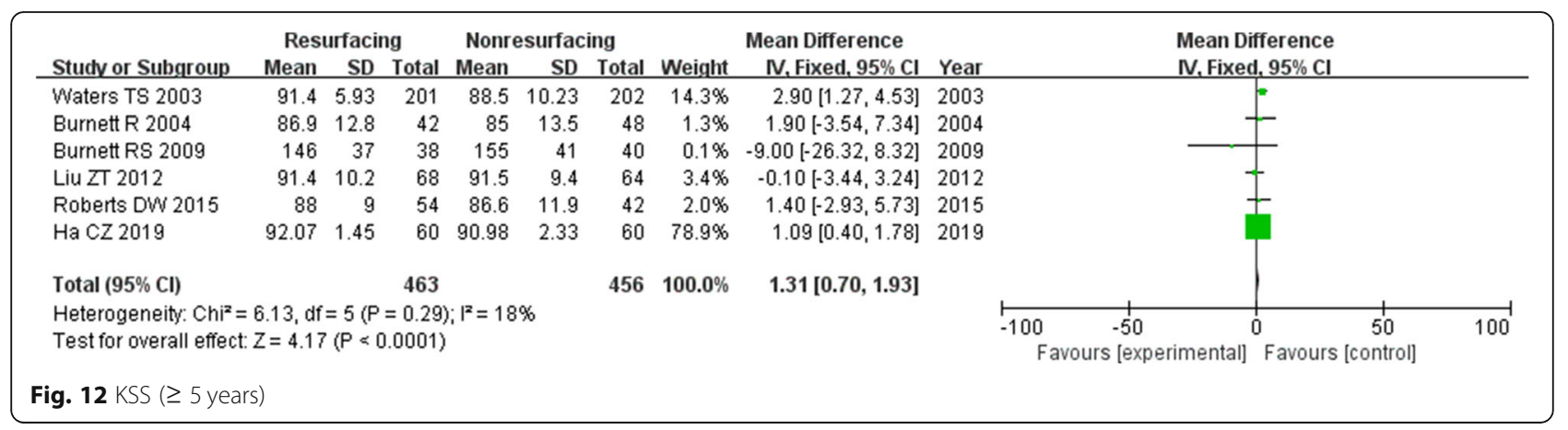

nonresurfacing. Twelve preferred patellar resurfacing for the reasons such as better results in mid-term evaluation, lower rate of reoperation, lower incidence of noise, lower complication rate, higher patients satisfaction, lower AKP rate and higher ROM result, while in Crawford et al.'s study [58], it seemed that TKA with patellar resurfacing had a higher incidence of manipulation under anaesthesia than nonresurfacing. Coory et al. [57] conducted a study of 570,735 TKAs followed up for 17 years from 1999 to 2017. They found that patellar resurfacing might reduce the rate of revision for both MS and PS knees, and the rate of reoperation for MS knees was the lowest. Especially, in Feng et al.'s two studies $[41,59]$ of Chinese people, there was no significant difference between resurfacing and nonresurfacing. We speculated that the race might influence the outcomes of patellar resurfacing. Furthermore, amongst the 15 meta-analysis or systemic reviews, the studies of Cheng et al. [61], Jonbergen et al. [62] and Grassi et al. [70] indicated that patellar resurfacing had no advantages with nonresurfacing. Petersen et al. [64] believed that the functional causes of AKP might be distinguished from mechanical causes, while Arirachakaran et al. [67] indicated that patellar denervation might improve the knee function but does not improve pain compared with patellar resurfacing. In the researches of Longo et al. [4], Tang et al. [71], Migliorini et al. [38] and Teel et al. [37], patellar resurfacing got the advantage in the following aspects: better KSS and function scores and lower reoperation rate. These 4 studies were carried out in the last 3 years including the latest RCTs preceding 2018. It showed the necessity for high-quality RCT research.

Some limitations of this study should be acknowledged: (1) data of RCTs were not fully reported; (2) the sample size and follow-up time were not close in different RCTs, which might cause heterogeneity; (3) some studies did not provide standard deviation, and this might cause the loose of some studies; (4) still we could not get the full text of few RCTs, which might cause bias; (5) the kind of knee prosthesis and

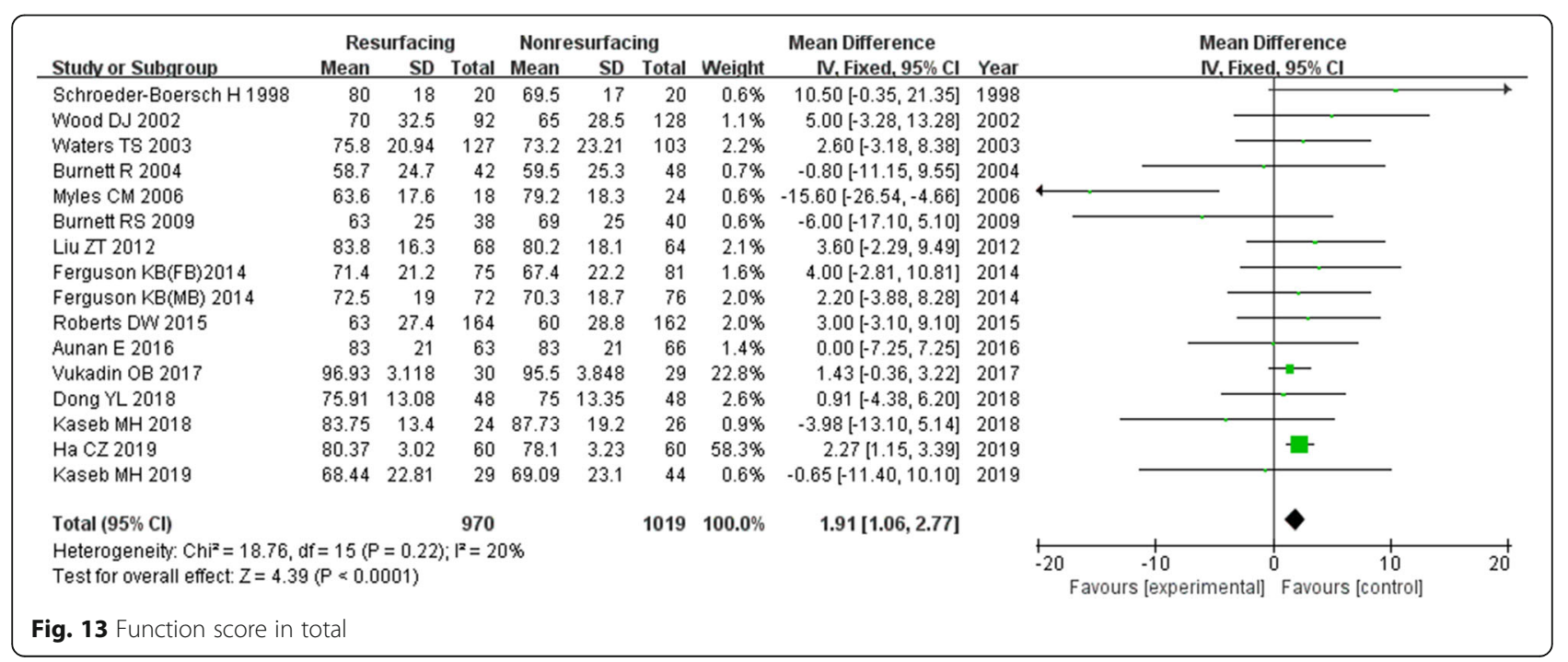




\begin{tabular}{|c|c|c|c|c|c|c|c|c|c|c|c|c|}
\hline \multirow[b]{2}{*}{ Studv or Subgroup } & \multicolumn{2}{|c|}{ Resurfacing } & \multicolumn{4}{|c|}{ Nonresurfacing } & \multirow{2}{*}{\multicolumn{2}{|c|}{$\begin{array}{l}\text { Mean Difference } \\
\text { IV. Random, } 95 \% \mathrm{Cl}\end{array}$}} & \multirow{2}{*}{\multicolumn{4}{|c|}{$\begin{array}{l}\text { Mean Difference } \\
\text { IV. Random. } 95 \% \mathrm{Cl}\end{array}$}} \\
\hline & Mean & SD & Total & Mean & SD & Total & & & & & & \\
\hline Schroeder-Boersch H 1998 & 80 & 18 & 20 & 69.5 & 17 & 20 & $2.1 \%$ & $10.50[-0.35,21.35]$ & 1998 & & & \\
\hline Myles CM 2006 & 63.6 & 17.6 & 18 & 79.2 & 18.3 & 24 & $2.1 \%$ & $-15.60[-26.54,-4.66]$ & 2006 & & & \\
\hline Liu ZT 2012 & 83.8 & 16.3 & 68 & 80.2 & 18.1 & 64 & $6.4 \%$ & $3.60[-2.29,9.49]$ & 2012 & & - & \\
\hline Ferguson KB(FB)2014 & 71.4 & 21.2 & 75 & 67.4 & 22.2 & 81 & $5.0 \%$ & $4.00[-2.81,10.81]$ & 2014 & & - & \\
\hline Ferguson KB(MB) 2014 & 72.5 & 19 & 72 & 70.3 & 18.7 & 76 & $6.1 \%$ & $2.20[-3.88,8.28]$ & 2014 & & - & \\
\hline Roberts DW 2015 & 63 & 27.4 & 164 & 60 & 28.8 & 162 & $6.0 \%$ & $3.00[-3.10,9.10]$ & 2015 & & - & \\
\hline Aunan E 2016 & 83 & 21 & 63 & 83 & 21 & 66 & $4.5 \%$ & $0.00[-7.25,7.25]$ & 2016 & & - & \\
\hline Vukadin OB 2017 & 96.93 & 3.118 & 30 & 95.5 & 3.848 & 29 & $26.7 \%$ & $1.43[-0.36,3.22]$ & 2017 & & & \\
\hline Kaseb MH 2018 & 83.75 & 13.4 & 24 & 87.73 & 19.2 & 26 & $3.0 \%$ & $-3.98[-13.10,5.14]$ & 2018 & & & \\
\hline Dong YL 2018 & 75.91 & 13.08 & 48 & 75 & 13.35 & 48 & $7.7 \%$ & $0.91[-4.38,6.20]$ & 2018 & & - & \\
\hline Ha CZ 2019 & 59.73 & 4.89 & 60 & 58.13 & 4.29 & 60 & $28.2 \%$ & $1.60[-0.05,3.25]$ & 2019 & & & \\
\hline Kaseb MH 2019 & 68.44 & 22.81 & 29 & 69.09 & 23.1 & 44 & $2.2 \%$ & $-0.65[-11.40,10.10]$ & 2019 & & & \\
\hline Total $(95 \% \mathrm{Cl})$ & & & 671 & & & 700 & $100.0 \%$ & $1.41[-0.22,3.05]$ & & & 1 & \\
\hline $\begin{array}{l}\text { Heterogeneity: } \operatorname{Tau}^{2}=1.76 ; 0 \\
\text { Test for owerall effect: } Z=1.7\end{array}$ & $\begin{array}{l}i^{2}=15 . \\
(P=0.0\end{array}$ & $\begin{array}{l}\text { o9, df }= \\
\text { 19) }\end{array}$ & $11(P=$ & $0.18) ;$ & $=27 \%$ & & & & & $\begin{array}{cc}-100 & -50 \\
\text { Favours [experimentall] }\end{array}$ & $\begin{array}{lc}0 & 50 \\
\text { Favours [control] }\end{array}$ & 100 \\
\hline Fig. 14 Function score $(\leq$ & jears) & & & & & & & & & & & \\
\hline
\end{tabular}

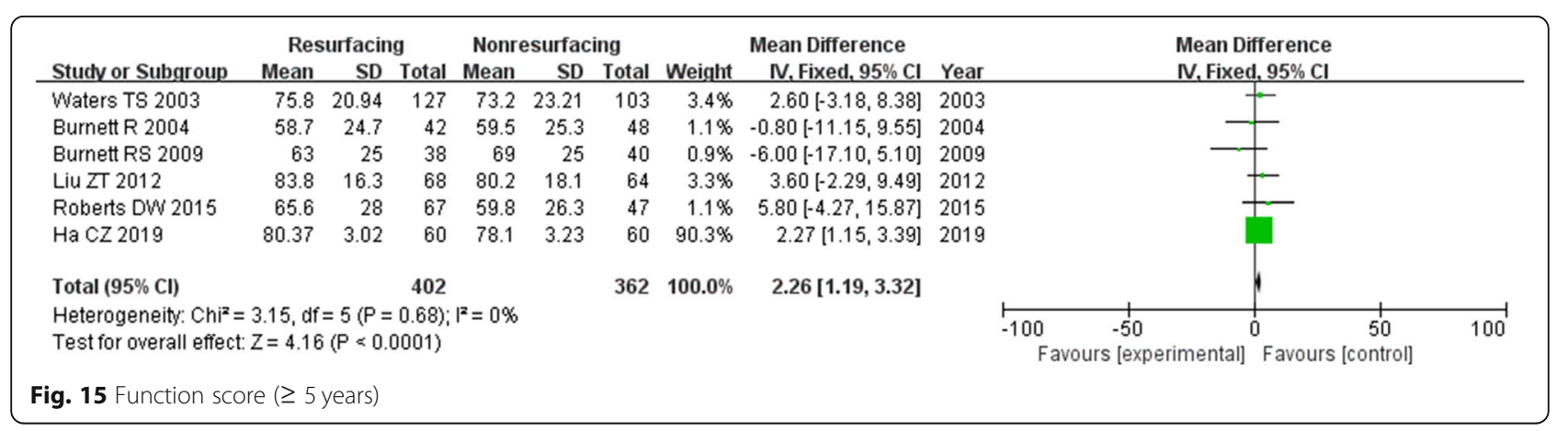

the race of the patients may affect the clinical outcomes as well as the result of this meta-analysis; and (6) the skills of surgeons might also influence the outcomes of each group, so a standard to assess the surgery skills was needed to avoid surgeon bias.

Compared with the above literatures, our study analysed more outcome indicators, included the latest RCTs until May 2020 and got updated conclusions. In addition, we suggested further research directions as follows: (1) more high-quality RCTs of large sample size and long-term follow-up (such as 5-10 years or even longer), (2) more RCTs about the influence of TKA prosthetic type on outcomes of patellar resurfacing, (3) more studies about different patellar resurfacing outcomes of osteoarthritis and rheumatoid arthritis, (4) RCTs about the influence of different grade of patellofemoral arthritis, (5) RCTs focus on the relationship between radiograph measurement (such as angles) and outcome indicators (such as complication, scores and pain), and (6) studies about different race.

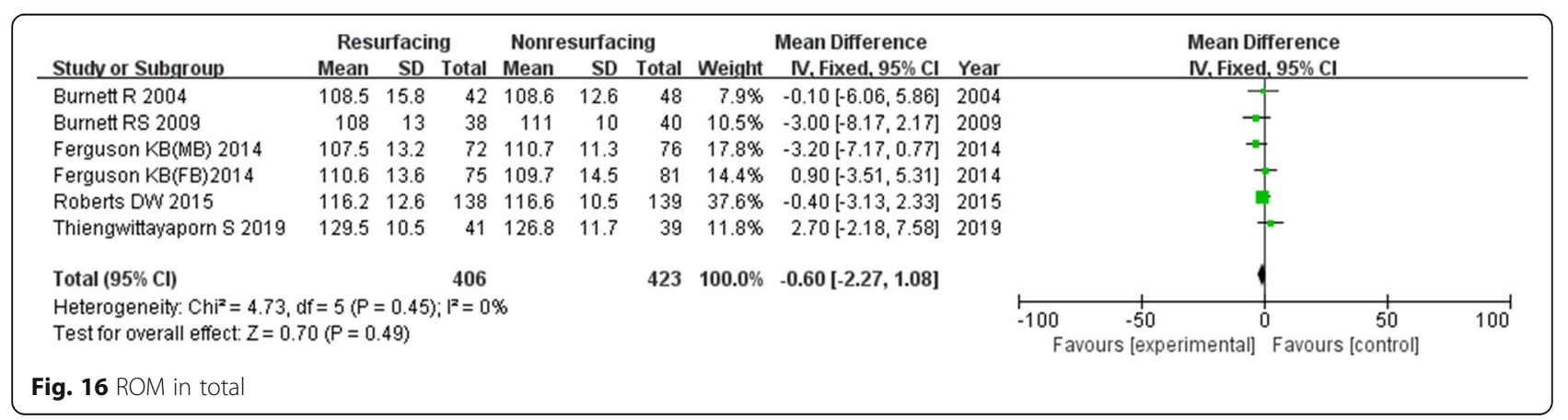




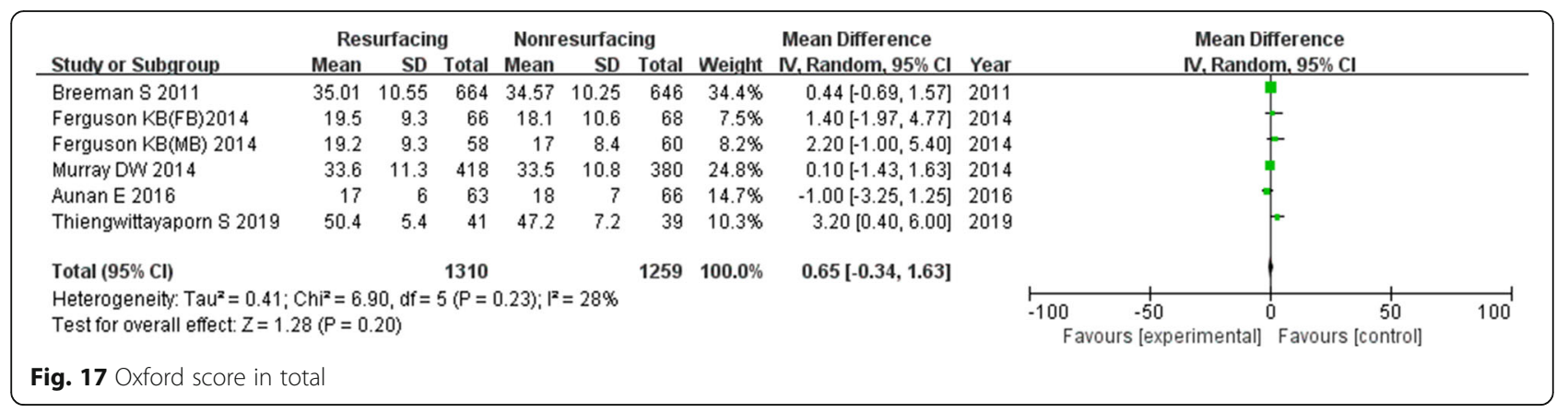

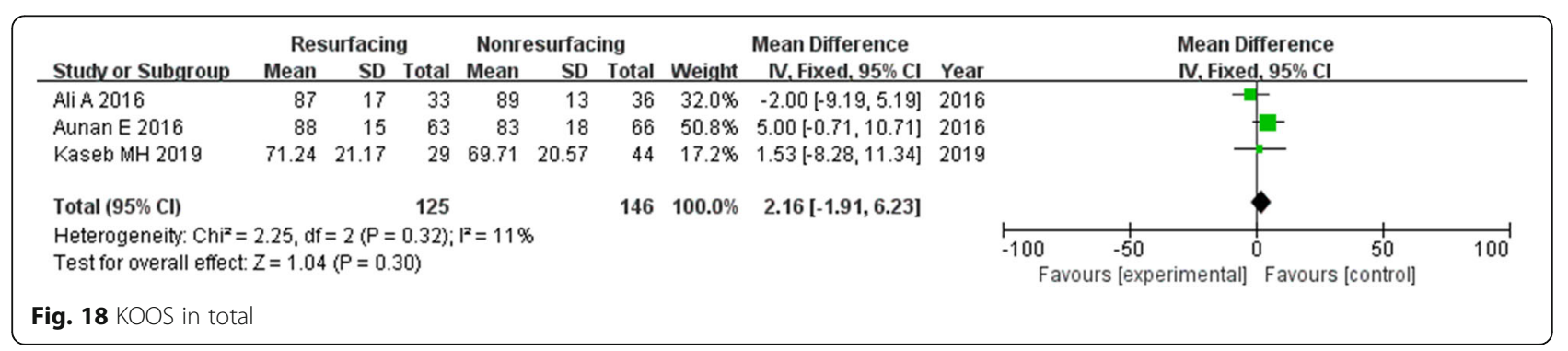

\begin{tabular}{|c|c|c|c|c|c|c|c|c|c|c|c|c|}
\hline \multirow[b]{2}{*}{ Stucty or Subgroup } & \multicolumn{2}{|c|}{ Resurfacing } & \multicolumn{2}{|c|}{ Nonresurfacing } & \multicolumn{3}{|c|}{ Odds Ratio } & \multirow{2}{*}{\multicolumn{5}{|c|}{$\begin{array}{c}\text { Odds Ratio } \\
\text { M-H. Random. } 95 \% \mathrm{Cl}\end{array}$}} \\
\hline & Events & Total & Events & Total & Weight & M-H, Random, $95 \% \mathrm{Cl}$ & Year & & & & om. $95 \% \mathrm{Cl}$ & \\
\hline Barrack R 2001 & 43 & 47 & 43 & 46 & $7.1 \%$ & $0.75[0.16,3.55]$ & 2001 & & & & & \\
\hline Mayman D 2003 & 50 & 50 & 48 & 50 & $2.6 \%$ & $5.21[0.24,111.24]$ & 2003 & & & & & \\
\hline Waters TS 2003 & 204 & 229 & 186 & 206 & $14.7 \%$ & $0.88[0.47,1.63]$ & 2003 & & & $\longrightarrow$ & - & \\
\hline Burnett R 2004 & 34 & 42 & 38 & 48 & $10.8 \%$ & $1.12[0.40,3.16]$ & 2004 & & & & & \\
\hline Smith AJ 2008 & 52 & 71 & 71 & 86 & $13.3 \%$ & $0.58[0.27,1.24]$ & 2008 & & & & & \\
\hline Liu ZT 2012 & 56 & 68 & 54 & 64 & $11.9 \%$ & $0.86[0.34,2.17]$ & 2012 & & & & & \\
\hline Ali A 2016 & 31 & 33 & 34 & 36 & $5.0 \%$ & $0.91[0.12,6.87]$ & 2016 & & & & & \\
\hline Dong YL 2018 & 13 & 48 & 10 & 48 & $11.7 \%$ & $1.41[0.55,3.63]$ & 2018 & & & & & \\
\hline Ha CZ 2019 & 28 & 60 & 4 & 60 & $10.0 \%$ & $12.25[3.94,38.08]$ & 2019 & & & & & \\
\hline Koh IJ 2019 & 22 & 45 & 22 & 45 & $12.8 \%$ & $1.00[0.44,2.29]$ & 2019 & & & & & \\
\hline Total $(95 \% \mathrm{Cl})$ & & 693 & & 689 & $100.0 \%$ & $1.24[0.73,2.10]$ & & & & & & \\
\hline Total events & 533 & & 510 & & & & & & & & & \\
\hline $\begin{array}{l}\text { Heterogeneity: Tauz } \\
\text { Test for overall effect }\end{array}$ & $\begin{array}{l}0.40 ; \mathrm{Chi}^{-} \\
\mathrm{Z}=0.78\end{array}$ & $\begin{array}{l}=22.79 \\
=0.44\end{array}$ & 9, $d f=9(P$ & $0.007) ;$ & $\left.\right|^{2}=61 \%$ & & & $\begin{array}{r}0.01 \\
F\end{array}$ & $\begin{array}{l}0.1 \\
\text { s [expe }\end{array}$ & ${ }_{\text {berimental] }}^{1}$ & $\begin{array}{c}10 \\
\text { Favours [control] }\end{array}$ & 100 \\
\hline
\end{tabular}




\section{Conclusion}

This study is an update meta-analysis of our previous study. We included more high-quality RCTs and analyse more outcomes. Subgroup analysis of different follow-up time is conducted. In conclusion, we find that patellar resurfacing could reduce the occurrence of reoperation and noise after surgery, as well as increase the KSS and function score, while it may not influence the results such as AKP, ROM, Oxford score, KOOS, VAS, Feller score, patellar tilt and the patients' satisfaction. The result is different from our previous meta-analysis. As a result of this new study, we prefer patellar resurfacing in TKA, while, still, more high-quality RCTs are expected eagerly.

\section{Abbreviations}

TKA: Total knee arthroplasty; KSS: Knee society score; AKP: Anterior knee pain; ROM: Range of motion; RCTs: Randomized controlled trials; KOOS: Knee injury and osteoarthritis outcome score; VAS: Visual analogue score

\section{Acknowledgements}

Ye Hong (13962780166@139.com) and Shiran Zhou (13615222133@139.com) also contributed to our study for their work on literature retrieval.

\section{Authors' contributions}

1. Objective: Kai Chen. 2. Data sources: Lidong Li and Zhigang Chen. 3. Study selection: Haidong Cui and Shujun LV. 4. Data extraction: Kai Chen and Xiaoyu Dai. 5. Data synthesis: Zhigang Chen and Haidong Cui. 6. Conclusions: Lidong Li and Shujun Lv. 7. Wrote the manuscript: Kai Chen and Xiaoyu Dai. The author (s) read and approved the final manuscript.

\section{Authors' information}

See on the title page.

\section{Funding}

Scientific Research Project of the Nantong Municipal Science and Technology Bureau (MSZ19024). Scientific Research Project of Nantong Health Bureau (QB2019013). Support for the literature search.

\section{Availability of data and materials}

Yes

\section{Ethics approval and consent to participate}

Not applicable

\section{Consent for publication}

Yes

\section{Competing interests}

The authors declare that they have no competing interests.

\section{Author details}

'Department of Orthopedic Surgery, Hai'an People's Hospital, Zhongba Road 17, Hai'an, Nantong 226600, Jiangsu, People's Republic of China. ${ }^{2}$ Department of Orthopedic Surgery, The First People's Hospital of Changzhou Affiliated to Soochow University, Juqian Road 185, Changzhou 213000, Jiangsu, People's Republic of China.

Received: 14 October 2020 Accepted: 25 December 2020 Published online: 25 January 2021

\section{References}

1. Hou C, Chu X, Zhang B, Li J, Dong Y, Zhao Y. Patellar resurfacing versus patellar nonresurfacing in primary total knee arthroplasty: a protocol for systematic review and meta analysis. Medicine (Baltimore). 2020;99(21): e20097. https://doi.org/10.1097/md.0000000000020097 PubMed PMID: 32481276 .
2. Calvisi V, Camillieri G, Lupparelli S. Resurfacing versus nonresurfacing the patella in total knee arthroplasty: a critical appraisal of the available evidence. Arch Orthop Trauma Surg. 2009;129(9):1261-70. https://doi.org/10. 1007/s00402-008-0801-9 Epub 2009/01/07 PubMed PMID: 19125261.

3. Burnett RS, Haydon CM, Rorabeck CH, Bourne RB. The John Insall Award: patella resurfacing versus nonresurfacing in total knee arthroplasty. Clin Orthop Relat Res 2004;428:12-25. doi: https://doi.org/10.1097/01.blo. 0000148594.05443.a3.

4. Longo UG, Ciuffreda M, Mannering N, D'Andrea V, Cimmino M, Denaro V. Patellar resurfacing in total knee arthroplasty: systematic review and metaanalysis. J Arthroplasty. 2018;33(2):620-32. https://doi.org/10.1016/j.arth.2017. 08.041 Epub 2017/10/17 PubMed PMID: 29032861

5. Chen K, Li G, Fu D, Yuan C, Zhang Q, Cai Z. Patellar resurfacing versus nonresurfacing in total knee arthroplasty: a meta-analysis of randomised controlled trials. Int Orthop. 2013;37(6):1075-83. https://doi.org/10.1007/ s00264-013-1866-9 Epub 2013/03/27 PubMed PMID: 23529719; PubMed Central PMCID: PMCPMC3664152.

6. Feller JA, Bartlett RJ, Lang DM. Patellar resurfacing versus retention in total knee arthroplasty. J Bone Joint Surg Br. 1996;78(2):226-8 Epub 1996/03/01. PubMed PMID: 8666630

7. Kajino A, Yoshino S, Kameyama S, Kohda M, Nagashima S. Comparison of the results of bilateral total knee arthroplasty with and without patellar replacement for rheumatoid arthritis. A follow-up note. J Bone Joint Surg Am. 1997;79(4):570-4 Epub 1997/04/01. PubMed PMID: 9111403.

8. Schroeder-Boersch H, Scheller G, Fischer J, Jani L. Advantages of patellar resurfacing in total knee arthroplasty. Two-year results of a prospective randomized study. Arch Orthop Trauma Surg. 1998;117(1-2):73-8. https:// doi.org/10.1007/BF00703446 Epub 1998/02/11PubMed PMID: 9457343.

9. Newman JH, Ackroyd CE, Shah NA, Karachalios T. Should the patella be resurfaced during total knee replacement? Knee. 2000;7(1):17-23 Epub 2000

10. Barrack RL, Bertot AJ, Wolfe MW, Waldman DA, Milicic M, Myers L. Patellar resurfacing in total knee arthroplasty. A prospective, randomized, doubleblind study with five to seven years of follow-up. J Bone Joint Surg Am. 2001:83(9):1376-81 Epub 2001/09/25. PubMed PMID: 11568201.

11. Wood DJ, Smith AJ, Collopy D, White B, Brankov B, Bulsara MK. Patellar resurfacing in total knee arthroplasty: a prospective, randomized trial. J Bone Joint Surg Am. 2002;84(2):187-93. https://doi.org/10.2106/00004623200202000-00004 Epub 2002/02/28 PubMed PMID: 11861723.

12. Mayman D, Bourne RB, Rorabeck $\mathrm{CH}$, Vaz M, Kramer J. Resurfacing versus not resurfacing the patella in total knee arthroplasty. J Arthroplasty. 2003; 18(5):541-5. https://doi.org/10.1016/s0883-5403(03)00150-5.

13. Waters TS, Bentley G. Patellar resurfacing in total knee arthroplasty. A prospective, randomized study. J Bone Joint Surg Am. 2003;85(2):212-7. https://doi.org/10.2106/00004623-200302000-00005 Epub 2003/02/07 PubMed PMID: 12571296

14. Gildone A, Manfredini M, Biscione R, Faccini R. Patella resurfacing in posterior stabilised total knee arthroplasty: a follow-up study in 56 patients. Acta Orthop Belg. 2005;71(4):445-51 Epub 2005/09/28. PubMed PMID: 16185000

15. Campbell DG, Duncan WW, Ashworth M, Mintz A, Stirling J, Wakefield L, et al. Patellar resurfacing in total knee replacement: a ten-year randomised prospective trial. J Bone Joint Surg Br. 2006;88(6):734-9. https://doi.org/10. 1302/0301-620X.88B6.16822 Epub 2006/05/25 PubMed PMID: 16720765.

16. Myles CM, Rowe PJ, Nutton RW, Burnett R. The effect of patella resurfacing in total knee arthroplasty on functional range of movement measured by flexible electrogoniometry. Clin Biomech (Bristol, Avon). 2006;21(7):733-9. https://doi.org/10.1016/j.clinbiomech.2006.02.008 Epub 2006/04/11 PubMed PMID: 16603285

17. Burnett RS, Boone JL, McCarthy KP, Rosenzweig S, Barrack RL. A prospective randomized clinical trial of patellar resurfacing and nonresurfacing in bilateral TKA. Clin Orthop Relat Res. 2007;464:65-72. https://doi.org/10.1097/ BLO.0b013e31812f783b Epub 2007/06/26 PubMed PMID: 17589364.

18. Smith AJ, Wood DJ, Li MG. Total knee replacement with and without patellar resurfacing: a prospective, randomised trial using the profix total knee system. J Bone Joint Surg Br. 2008;90(1):43-9. https://doi.org/10.1302/ 0301-620X.90B1.18986 Epub 2007/12/28 PubMed PMID: 18160498.

19. Burnett RS, Boone JL, Rosenzweig SD, Steger-May K, Barrack RL. Patellar resurfacing compared with nonresurfacing in total knee arthroplasty. A concise follow-up of a randomized trial. J Bone Joint Surg Am. 2009;91(11): 2562-7. https://doi.org/10.2106/JBJS.H.00109 Epub 2009/11/04 PubMed PMID: 19884428 
20. Breeman S, Campbell M, Dakin H, Fiddian N, Fitzpatrick R, Grant A, et al. Patellar resurfacing in total knee replacement: five-year clinical and economic results of a large randomized controlled trial. J Bone Joint Surg Am. 2011;93(16):1473-81. https://doi.org/10.2106/JBJS.J.00725 Epub 2011/ 12/29. PubMed PMID: 22204002.

21. Beaupre L, Secretan C, Johnston DW, Lavoie G. A randomized controlled trial comparing patellar retention versus patellar resurfacing in primary total knee arthroplasty: 5-10 year follow-up. BMC Res Notes. 2012;5:273. https:// doi.org/10.1186/1756-0500-5-273 Epub 2012/06/09 PubMed PMID: 22676495; PubMed Central PMCID: PMCPMC3532201.

22. Liu ZT, Fu PL, Wu HS, Zhu Y. Patellar reshaping versus resurfacing in total knee arthroplasty - results of a randomized prospective trial at a minimum of 7 years' follow-up. Knee. 2012;19(3):198-202. https://doi.org/10.1016/j. knee.2011.03.004 Epub 2011/04/26 PubMed PMID: 21515055.

23. Ferguson KB, Bailey O, Anthony I, James PJ, Stother IG. M JGB. A prospective randomised study comparing rotating platform and fixed bearing total knee arthroplasty in a cruciate substituting design--outcomes at two year followup. Knee. 2014;21(1):151-5. https://doi.org/10.1016/j.knee.2013.09.007 Epub 2013/10/23 PubMed PMID: 24145068.

24. Murray DW, MacLennan GS, Breeman S, Dakin HA, Johnston L, Campbell MK, et al. A randomised controlled trial of the clinical effectiveness and cost-effectiveness of different knee prostheses: the Knee Arthroplasty Trial (KAT). Health Technol Assess. 2014;18(19):1-235, vii-viii. doi: https://doi.org/ 10.3310/hta18190. Epub 2014/04/01 PubMed PMID: 24679222; PubMed Central PMCID: PMCPMC4781565

25. Sreehari CKNS. Patellar resurfacing compared with non-resurfacing in total knee arthroplasty: a 5-year follow-up study. OA Orthop. 2014;11(2(2)):13

26. Roberts DW, Hayes TD, Tate CT, Lesko JP. Selective patellar resurfacing in total knee arthroplasty: a prospective, randomized, double-blind study. J Arthroplasty. 2015;30(2):216-22. https://doi.org/10.1016/j.arth.2014.09.012 Epub 2014/10/16 PubMed PMID: 25316378.

27. Ali A, Lindstrand A, Nilsdotter A, Sundberg M. Similar patient-reported outcomes and performance after total knee arthroplasty with or without patellar resurfacing. Acta Orthop. 2016;87(3):274-9. https://doi.org/10.3109/ 17453674.2016.1170548 Epub 2016/05/24 PubMed PMID: 27212102; PubMed Central PMCID: PMCPMC4900081.

28. Aunan E, Næss G, Clarke-Jenssen J, Sandvik L, Kibsgård TJ. Patellar resurfacing in total knee arthroplasty: functional outcome differs with different outcome scores: a randomized, double-blind study of 129 knees with 3 years of follow-up. Acta Orthop. 2016;87(2):158-64. https://doi.org/10. 3109/17453674.2015.1111075 Epub 2015/11/06 PubMed PMID: 26540368; PubMed Central PMCID: PMCPMC4812078

29. Vukadin OB, Blagojević ZB, Baščarević ZL, Slavković NS, Stevanović V, Vukomanović BD. The importance of patellar resurfacing in total knee arthroplasty for symptomatic valgus degenerative deformity. Acta Chir Orthop Traumatol Cech. 2017;84(1):30-4 Epub 2017/03/04. PubMed PMID: 28253943

30. Dong $Y, L i T$, Zheng $Z$, Xiang $S$, Weng $X$. Adding patella resurfacing after circumpatellar electrocautery did not improve the clinical outcome in bilateral total knee arthroplasty in Chinese population: a prospective randomized study. J Arthroplasty. 2018;33(4):1057-61. https://doi.org/10. 1016/j.arth.2017.10.039 Epub 2017/12/02 PubMed PMID: 29191442.

31. Kaseb MH, Tahmasebi MN, Mortazavi SJ, Sobhan MR, Nabian MH. Comparison of clinical results between patellar resurfacing and nonresurfacing in total knee arthroplasty: a short term evaluation. Arch Bone Jt Surg. 2018;6(2):124-9 Epub 2018/03/31. PubMed PMID: 29600265; PubMed Central PMCID: PMCPMC5867356.

32. Ha C, Wang B, Li W, Sun K, Wang D, Li Q. Resurfacing versus not-resurfacing the patella in one-stage bilateral total knee arthroplasty: a prospective randomized clinical trial. Int Orthop. 2019;43(11):2519-27. https://doi.org/10. 1007/s00264-019-04361-7 Epub 2019/06/23 PubMed PMID: 31227852; PubMed Central PMCID: PMCPMC6848038.

33. Kaseb MH, Mortazavi J, Ayati Firoozabadi M, Toofan H. Comparison between patellar resurfacing and retention in total knee arthroplasty regarding the postoperative satisfaction of patients and patellar crepitus. Arch Bone Jt Surg. 2019;7(5):441-4 Epub 2019/11/20. PubMed PMID: 31742221; PubMed Central PMCID: PMCPMC6802549.

34. Koh IJ, Kim MS, Sohn S, Song KY, Choi NY, In Y. Patients undergoing total knee arthroplasty using a contemporary patella-friendly implant are unaware of any differences due to patellar resurfacing. Knee Surg Sports
Traumatol Arthrosc. 2019;27(4):1156-64. https://doi.org/10.1007/s00167-0185120-2 Epub 2018/08/23 PubMed PMID: 30132051.

35. Thiengwittayaporn S, Srungboonmee K, Chiamtrakool B. Resurfacing in a posterior-stabilized total knee arthroplasty reduces patellar crepitus complication: a randomized, controlled trial. J Arthroplasty. 2019;34(9):196974. https://doi.org/10.1016/j.arth.2019.04.050 Epub 2019/05/28 PubMed PMID: 31126775

36. TMv R, Evd M, AJd V, JJAMv R. Patellar resurfacing does not improve clinical outcome in patients with symptomatic tricompartmental knee osteoarthritis, An RCT study of 40 patients receiving primary cruciate retaining total knee arthroplasty. J Knee Surg. 2020. https://doi.org/10.1055/ s-0040-1710369 PubMed PMID: 32434236.

37. Teel AJ, Esposito JG, Lanting BA, Howard JL, Schemitsch EH. Patellar resurfacing in primary total knee arthroplasty: a meta-analysis of randomized controlled trials. J Arthroplasty. 2019;34(12):3124-32. https://doi. org/10.1016/j.arth.2019.07.019 Epub 2019/08/21 PubMed PMID: 31427130.

38. Migliorini F, Eschweiler J, Niewiera M, El Mansy Y, Tingart M, Rath B. Better outcomes with patellar resurfacing during primary total knee arthroplasty: a meta-analysis study. Arch Orthop Trauma Surg. 2019;139(10):1445-54. https://doi.org/10.1007/s00402-019-03246-z Epub 2019/08/02 PubMed PMID: 31367842

39. Keremu A, Maimaitiaili H, Shan P, Abudu A. Effect of patellar non-resurfacing on clinical results after total knee arthroplasty. Zhongguo Xiu Fu Chong Jian Wai Ke Za Zhi. 2013:27(10):1157-61 Epub 2014/01/09. PubMed PMID: 24397122

40. Vasconcelos JW. Leite LMdS, Sousa JCA, Sousa JOMd, Santos E Santos MF. Medium-term evaluation of total knee arthroplasty without patellar replacement. Revista brasileira de ortopedia. 2013;48(3):251-6. https://doi. org/10.1016/j.rboe.2012.02.002 PubMed PMID: 31214541

41. Feng B, Weng $X$, Lin J, Jin J, Qian W, Wang W, et al. Long term follow up of clinical outcome between patellar resurfacing and nonresurfacing in total knee arthroplasty: Chinese experience. Chin Med J (Engl). 2014;127(22): 3845-51 Epub 2014/11/26. PubMed PMID: 25421178.

42. Sandiford NA, Alao U, Salamut W, Weitzel S, Skinner JA. Patella resurfacing during total knee arthroplasty: have we got the issue covered? Clin Orthop Surg. 2014;6(4):373-8. https://doi.org/10.4055/cios.2014.6.4.373 Epub 2014/ 12/02 PubMed PMID: 25436059; PubMed Central PMCID: PMCPMC4233214.

43. Schiavone Panni A, Cerciello S, Del Regno C, Felici A, Vasso M. Patellar resurfacing complications in total knee arthroplasty. Int Orthop. 2014;38(2): 313-7. https://doi.org/10.1007/s00264-013-2244-3 Epub 2013/12/24 PubMed PMID: 24363045; PubMed Central PMCID: PMCPMC3923924.

44. Kim SH, Lee S, Ro du H, Cho Y, Lee YM, Chung KY, et al. Comparison of patellar resurfacing versus preservation in high flexion total knee arthroplasty. Knee Surg Sports Traumatol Arthrosc 2015;23(6):1782-1790. doi: https://doi.org/10. 1007/s00167-014-3278-9. Epub 2014/09/17 PubMed PMID: 25223965.

45. Albrecht DC, Ottersbach A. Retrospective 5-year analysis of revision rate and functional outcome of TKA with and without patella implant. Orthopedics. 2016;39(3 Suppl):S31-5. https://doi.org/10.3928/01477447-20160509-07 Epub 2016/05/25 PubMed PMID: 27219724

46. Etchebehere M, Lin PP, Bird JE, Satcher RL, Moon BS, Yu J, et al. Patellar resurfacing: does it affect outcomes of distal femoral replacement after distal femoral resection? J Bone Joint Surg Am. 2016;98(7):544-51. https:// doi.org/10.2106/jbjs.0.00633 Epub 2016/04/08 PubMed PMID: 27053582; PubMed Central PMCID: PMCPMC6948835.

47. Ogawa $\mathrm{H}$, Matsumoto $\mathrm{K}$, Akiyama $\mathrm{H}$. Effect of patellar resurfacing on patellofemoral crepitus in posterior-stabilized total knee arthroplasty. J Arthroplasty. 2016;31(8):1792-6. https://doi.org/10.1016/j.arth.2016.01.023 Epub 2016/03/08 PubMed PMID: 26948175.

48. Maradit-Kremers H, Haque OJ, Kremers WK, Berry DJ, Lewallen DG, Trousdale $\mathrm{RT}$, et al. Is selectively not resurfacing the patella an acceptable practice in primary total knee arthroplasty? J Arthroplasty. 2017;32(4):1143-7. https:// doi.org/10.1016/j.arth.2016.10.014 Epub 2016/11/24 PubMed PMID: 27876254

49. Zicaro JP, Yacuzzi C, Astoul Bonorino J, Carbo L, Costa-Paz M. Patellofemoral arthritis treated with resurfacing implant: clinical outcome and complications at a minimum two-year follow-up. Knee. 2017;24(6):1485-91. https://doi.org/10.1016/j.knee.2017.09.003 Epub 2017/10/13 PubMed PMID: 29021089.

50. Adravanti P, Tecame A, de Girolamo L, Ampollini A, Papalia R. Patella resurfacing in total knee arthroplasty: a series of 1280 patients at midterm follow-up. J Arthroplasty. 2018;33(3):696-9. https://doi.org/10.1016/j.arth. 2017.09.050 Epub 2017/10/28 PubMed PMID: 29074323. 
51. Agarwala S, Shetty V, Karumuri LK, Vijayvargiya M. Patellar resurfacing versus nonresurfacing with patellaplasty in total knee arthroplasty. Indian J Orthop. 2018;52(4):393-8. https://doi.org/10.4103/ortho.IJOrtho_512_16 Epub 2018/ 08/07 PubMed PMID: 30078898; PubMed Central PMCID: PMCPMC6055458.

52. Perrone FL, Baron S, Suero EM, Lausmann C, Kendoff D, Zahar A, et al. Patient-reported outcome measures (PROMs) in patients undergoing patellofemoral arthroplasty and total knee replacement: a comparative study. Technol Health Care. 2018;26(3):507-14. https://doi.org/10.3233/thc181185 Epub 2018/04/05 PubMed PMID: 29614710.

53. Korkmaz O, Genc Y, Cimen O, Oltulu I, Gülabi D, Cecen G. Effect of patellar resurfacing on clinical outcomes, range of knee motion and anterior knee pain in patients with total knee arthroplasty. Serbian J Exp Clin Res. 2019;20(4):30912. https://doi.org/10.2478/sjecr-2018-0067 PubMed PMID: 141602871.

54. Kornah BA, Negm MAE, Megahed MAM. Short term outcomes of nonsurfacing patelloplasty in primary total knee arthroplasty. Egypt J Hosp Med. 2019;75(1):2089-91 PubMed PMID: 135882445

55. Paul-Gabriel B, Feier A, Mădălina-Cerasela B, Octav RM. Quality of life after total knee arthroplasty without patellar resurfacing. Acta Med Marisiensis. 2019:65:24 PubMed PMID: 136920040.

56. Rajanish R, Harisankar M, Malayil JT, PK M. Functional outcome of nonresurfacing patelloplasty in primary total knee arthroplasty-a one year follow up study of 62 knee replacements. Kerala J Orthop. 2019;32(2):2-5. https:// doi.org/10.13107/kjo.2019.v32i02.013 PubMed PMID: 142418555.

57. Coory JA, Tan KG, Whitehouse SL, Hatton A, Graves SE, Crawford RW. The outcome of total knee arthroplasty with and without patellar resurfacing up to 17 years: a report from the Australian Orthopaedic Association National Joint Replacement Registry. J Arthroplasty. 2020;35(1):132-8. https://doi.org/ 10.1016/j.arth.2019.08.007 Epub 2019/09/04 PubMed PMID: 31477541.

58. Crawford DA, Hurst JM, Morris MJ, Berend KR. Does patellar resurfacing in primary total knee arthroplasty increase the risk of manipulation? Surg Technol Int. 2020;36:299-303 Epub 2020/03/21. PubMed PMID: 32196562.

59. Feng $B$, Ren $Y$, Lin J, Jin J, Qian W, Weng X. No difference in clinical outcome and survivorship after total knee arthroplasty with patellar resurfacing and nonresurfacing after minimum 10-year follow-up. Medicine (Baltimore). 2020;99(11):e19080. https://doi.org/10.1097/md. 0000000000019080 Epub 2020/03/17PubMed PMID: 32176033.

60. Huish EG Jr, Coury JG, Ummel JR, Deans JT, Cohen J, Casey JJ Jr. Higher rate of kneeling after primary knee arthroplasty without patellar resurfacing at midterm review. J Orthop. 2020;20:204-6. https://doi.org/10.1016/j.jor.2019. 11.008 Epub 2020/02/07 PubMed PMID: 32025150; PubMed Central PMCID: PMCPMC6997512.

61. Cheng T, Zhu C, Guo Y, Shi S, Chen D, Zhang X. Patellar denervation with electrocautery in total knee arthroplasty without patellar resurfacing: a meta-analysis. Knee Surg Sports Traumatol Arthrosc. 2014;22(11):2648-54. https://doi.org/10.1007/s00167-013-2533-9 Epub 2013/06/08 PubMed PMID: 23743580

62. Jonbergen H-P, Reuver J, Mutsaerts E, Poolman R. Determinants of anterior knee pain following total knee replacement: a systematic review. Knee Surg Sports Traumatol Arthrosc. 2014:22(3):478-99. https://doi.org/10.1007/ s00167-012-2294-x PubMed PMID: 94449866.

63. Li T, Zhou L, Zhuang Q, Weng $X$, Bian Y. Patellar denervation in total knee arthroplasty without patellar resurfacing and postoperative anterior knee pain: a meta-analysis of randomized controlled trials. J Arthroplasty. 2014; 29(12):2309-13. https://doi.org/10.1016/j.arth.2014.01.024 Epub 2014/03/04 PubMed PMID: 24582160.

64. Petersen W, Rembitzki IV, Brüggemann GP, Ellermann A, Best R, Koppenburg $A G$, et al. Anterior knee pain after total knee arthroplasty: a narrative review. Int Orthop. 2014;38(2):319-28. https://doi.org/10.1007/s00264-013-2081-4 Epub 2013/09/24 PubMed PMID: 24057656; PubMed Central PMCID: PMCP MC3923935

65. van Jonbergen HP, Reuver JM, Mutsaerts EL, Poolman RW. Determinants of anterior knee pain following total knee replacement: a systematic review. Knee Surg Sports Traumatol Arthrosc. 2014;22(3):478-99. https://doi.org/10. 1007/s00167-012-2294-x Epub 2012/11/20 PubMed PMID: 23160846.

66. Antholz CR, Cherian JJ, Elmallah RK, Jauregui JJ, Pierce TP, Mont MA. Selective patellar resurfacing: a literature review. Surg Technol Int. 2015;26: 355-60 Epub 2015/06/10. PubMed PMID: 26055032.

67. Arirachakaran A, Sangkaew C, Kongtharvonskul J. Patellofemoral resurfacing and patellar denervation in primary total knee arthroplasty. Knee Surg Sports Traumatol Arthrosc. 2015:23(6):1770-81. https://doi.org/10.1007/ s00167-014-3311-z Epub 2014/09/15 PubMed PMID: 25218579.
68. Findlay I, Wong F, Smith C, Back D, Davies A, Ajuied A. Non-resurfacing techniques in the management of the patella at total knee arthroplasty: a systematic review and meta-analysis. Knee. 2016;23(2):191-7. https://doi.org/ 10.1016/j.knee.2015.10.012 Epub 2016/02/06 PubMed PMID: 26846465.

69. van Jonbergen HP, Boeddha AV, van Raaij JJ. Patient satisfaction and functional outcomes following secondary patellar resurfacing. Orthopedics. 2016;39(5):e850-6. https://doi.org/10.3928/01477447-20160509-05 Epub 2016/05/14 PubMed PMID: 27172365.

70. Grassi A, Compagnoni R, Ferrua P, Zaffagnini S, Berruto M, Samuelsson K, et al. Patellar resurfacing versus patellar retention in primary total knee arthroplasty: a systematic review of overlapping meta-analyses. Knee Surg Sports Traumatol Arthrosc. 2018;26(11):3206-18. https://doi.org/10.1007/ s00167-018-4831-8 Epub 2018/01/18 PubMed PMID: 29335747.

71. Tang XB, Wang J, Dong PL, Zhou R. A Meta-analysis of patellar replacement in total knee arthroplasty for patients with knee osteoarthritis. J Arthroplasty. 2018;33(3):960-7. https://doi.org/10.1016/j.arth.2017.10.017 Epub 2017/12/02 PubMed PMID: 29191443.

\section{Publisher's Note}

Springer Nature remains neutral with regard to jurisdictional claims in published maps and institutional affiliations.

\section{Ready to submit your research? Choose BMC and benefit from:}

- fast, convenient online submission

- thorough peer review by experienced researchers in your field

- rapid publication on acceptance

- support for research data, including large and complex data types

- gold Open Access which fosters wider collaboration and increased citations

- maximum visibility for your research: over $100 \mathrm{M}$ website views per year

At BMC, research is always in progress.

Learn more biomedcentral.com/submissions 